\title{
LATE ANTIQUE AND EARLY MEDIEVAL RUPESTRIAN MONASTICISM IN THE IBERIAN PENINSULA LANDSCAPES AND MATERIAL CONTEXTS OF THE RUPESTRIAN SETTLEMENTS
}

\section{JORGE LÓPEZ QUIROGA}

UDC: $726.71(365)$

$27-788(365)$

Preliminary communication

Manuscript received: 05. 03. 2017.

Revised manuscript accepted: 20. 02. 2017.

DOI: 10.1484/J.HAM.5.113708

\author{
J. López Quiroga \\ Universidad Autónoma de Madrid (UAM) \\ Pabellón C (1 1 planta, despacho no ${ }^{12}$ ) \\ C/Einstein, 11, Carretera de Colmenar, Km. 15 \\ E-28o49 Madrid, España \\ jorge.quiroga@uam.es
}

Rupestrian architecture have been traditionally linked to hermits environments, considering them as isolated because of their topographical features and 'disconnected' from the rest of the world. But if we look carefully to their places of location in relation to the existing network of settlement, roads and circuits of production and consumption, the reality is somewhat different. In this sense, the rupestrian architecture linked to monastic communities formed authentic rural settlements, while Christian cult complex, in which a community not exclusively dedicated to religious activities conduct their daily life, because there would not be composed only of monks (as evidenced by their burial areas), forming what we might call "agricultural monasteries" or "village communities", in which the religious element would be a factor of social cohesion. In the Iberian Peninsula these are generally cult spaces of individual or collective character, with annexes spatial areas equipped with various functionalities. The topographical location of these sites in Hispania is very characteristic, taking advantage of mountainous areas and crags. Nevertheless, his situation is not defined by its "isolation" or "the flight to the desert", but because of its proximity to the settlement and communication network system.

Keywords: Rupestrian Christian Architecture, hermits, Monasticism, Iberian Peninsula, monks of the desert, agricultural monasteries, village communities, abbot, funeral area, monastery

\section{THE MEDITERRANEAN RUPESTRIAN CHRISTIAN LANDSCAPE: A COMPLEX PHENOMENON}

The architectures carved into stone are a typical human realization from the early times to our days. We know a considerable number of rupestrian sites for the whole Mediterranean, and we can also affirm that the rupestrian habitat is a distinctive element of the Mediterranean Landscape observable in Egypt, Ethiopia, the Anatolian Peninsula, the Balkans area, Greece, Italy, France and Spain. Certainly, geology is an important element in the rupestrian architecture, and all Mediterranean rupestrian sites showed similar geological and morphological conditions. The architectural solutions are linked to material needs; but at the same time they show specific and local solutions according to the kind of stone, to the behaviours and to the climate of the area. In Turkey, the original landscape of Cappadocia is due to the volcanic eruptions, which originated a soft rock that allows the characteristic construction of the rupestrian villages (as the underground complex of Derinkuyu, with seven excavated levels in the tuff) ${ }^{1}$. The morphology of these places develops plateaus due to volcanic eruptions (as in Cappadocia), which deposits soft materials (as tuffs) that could be excavated with rudimental tools. These spaces were used in the past as churches, cemeteries, depots, recoveries, houses, etc.

Traditionally, this type of architecture was linked to the eremitic phenomenon and in this sense the East Mediterranean (Egypt and Turkey over all, and also Syria, Lebanon, or Palestine) has been seen as the paradigmatic area of their origin and expansion. The so-called 'monks of the desert' took advantage of the rocky hollows and natural caves to build Christian cult places and housing spaces to implement his idea of ascetic lifestyle. But in fact we found in the Italian Catacombs (at Rome, Naples or Sicily) the true origin of the Rupestrian Christian Architecture with the construction of cult spaces employing imaginative architectural solutions to create individual monumental burial places and collective funerary areas and churches. Indeed, is in the Catacombs where we find some of the typical architectural elements of this rock architecture, and particularly two ideas that has deeply conditioned the study and interpretation of such structures: "run away and hide".

\section{THE RUPESTRIAN ARCHITECTURE IN THE IBERIAN PENINSULA: PRELIMINARY OBSERVATIONS}

The Iberian Peninsula is one of the most riches areas with rupestrian architecture around the Mediterranean. The distribution of these constructions is visible in the whole Iberian Peninsula and depends primarily of climatic and geological circumstances; but there are also historical reasons that explain some particularly geographical concentrations, as in the case of the Ebro Valley or in the southeast of Andalusia (cave churches are mainly focused in the province of Málaga). The existence of cave hermitages and rock churches is more intense in the north/northeast and in the southeast of the Iberian Peninsula; and the explanation of this phenomenon was usually connected with the so-called Reconquista and Repoblación process. In fact, and saving the obvious differences of historical context with the Catacombs, we meet again the ideas of "run away" and "hide".

Other important element should be taking into account for the Iberian Peninsula: the frontier. The idea of the frontier has led to what in the historiography has been called as "frontier societies" ${ }^{2}$ and, in the case of the religious architec-

\footnotetext{
${ }^{1}$ Not only in Cappadocia, but also in France we found undergrounds settlements as Naours (Picardie), with a simple level 33m underground and three hundred rooms.

${ }^{2}$ J. LÓPEZ QUIROGA, El concepto de frontera en las 'Españas' medievales, in G. Vannini - M. Nucciotti (eds.), Trans-Jordan in 12th and 13th centuries and the 'frontiers' of medieval Mediterranean (Limina/Limites. Archaeology, History, and borders the Mediterranean islands, 365-1556), Oxford, 2012, p. 476- 478.
} 
ture, a "religiosity frontier"3. Although the religious motives of these movements, generally associated with hermits, have always been taken into account, its connection with the Reconquista process and the repopulation in the north, and with the existence of Christian communities under Islamic rule in Al-Andalus in the south, still have a greater weight in the historiography.

We have a broad range of research about Christian rupestrian structures for the Iberian Peninsula, carried out generally in the framework of catalogues, inventories, monographs and also some doctoral thesis of local and regional level. All this studies have been made for very specific and very heterogeneous geographical areas: Catalonia and the Ebro valley ${ }^{4}$, Cantabria ${ }^{5}$, the Basque Country ${ }^{6}$, Palencia ${ }^{7}$, Salamanca ${ }^{8}$, Cáceres 9 , "La Rioja" ${ }^{10}$, eastern Andalusia", the northwest of the Iberian Peninsula ${ }^{12}$, the surroundings of Ciudad Rodrigo (Salamanca) ${ }^{13}$ or the Portuguese region of Riba Côa ${ }^{14}$; among others. 3 About the so-called 'frontier architecture' of the $10^{\text {th }}$ century in the Iberian Peninsula: A. M. MARTÍNEZ TEJERA, Estudios sobre las 'iglesias arabizadas'
del s. X en el reino de León, Saarbrücken, 2016.
${ }^{4}$ M. RIUU, Cuevas, eremitorios y centros cenobíticos rupestres en Andalucía Oriental, in VIII Congreso Internacional de Arqueología Cristiana, Ciudad del
Vaticano, 1972, p. 431-443; ID., Poblados mozárabes de Al-Andalus. Hipótesis para su estudio: el ejemplo de Busquistar, in Cuadernos de Estudios Medievales,
II-III, 1974-1975, p. 3-35; ID., Marmuyas, sede de una población mozárabe en los montes de Málaga, in Mainake, II, 1980, p. 235-262; J. BOLÓS I MASCLANS
- M. PAGES I PARETAS, Les sepultures excavades a la roca, in M. Ríu, (ed.), Necròpolis i sepultures medievals de Catalunya. Annex 1 de Acta Mediaevalia,
Barcelona, 1982, p. 59-103; J.I. PADILLA LAPUENTE, Yacimiento arqueológico de Cuyacabras: despoblado, iglesia y necrópolis. Eremitorio de Cueva Andrés.
Quintanar de la Sierra (Burgos), Barcelona, 2003; J.I. PADILLA LAPUENTE - K. ÁLVARO RUEDA, Necrópolis rupestres y el poblamiento altomedieval en el
alto Arlanza (Burgos), in En la España Medieval, 33, 2010, p. 259-294; ID., Asentamientos altomedievales y otras manifestaciones rupestres del alto Arlanza,
in J. López Quiroga - A. M. Martínez Tejera (eds.), In concavis petrarum habitaverunt. El fenómeno rupestre en el mediterráneo medieval. De la investigación
a la puesta en valor (Series Aslaeme, Proceedings 4, BAR International Series 2591), Oxford, 2014, p. 224-247.

${ }^{5}$ F. ÍNIIGUEZ ALMECH, Algunos problemas de las viejas iglesias españolas, in Cuadernos de Trabajo de la Escuela Española de Historia y Arqueología en Roma, VII, 1955, p. 9-18o; J. GONZÁLEZ ECHEGARAY - M. CARRIÓN IRÚN - A. PÉREZ DE REGULES, Las iglesias rupestres de Arroyuelos y Las Presillas, in Altamira, 1-3, 1961, p. 3-27; M. CARRIÓN IRÚN, El Prerrománico en Santander, in La Edad Media en Cantabria, Santander, 1973, p. 37-57; M. CARRIÓN IRÚN - M. A. GARCÍA GUINEA, Las iglesias rupestres de la época de la repoblación en la región cantábrica, in Congresso Luso Espanhol de Estudos Medievais, Porto, 1968, p. 311-314; R. BOHIGAS ROLDÁN, Las iglesias rupestres de Valderredible, Aguilar de Campoo, 1977; ID., Aproximación al fenómeno rupestre del alto valle del Ebro (Cantabria, Palencia, Burgos), in J. López Quiroga - A. M. Martínez Tejera (eds.), op. cit. (n. 4), p. 152-196; R. BOHIGAS - V. IRALA - J. F. MENÉNDEZ, Cuevas artificiales de Valderredible, Santander, in Sautuola, III, 192, p. 279-294; L. A. Monreal Jimeno, Eremitorios Rupestres Altomedievales (El Alto Valle del Ebro) (Cuadernos de Arqueología de Deusto 12), Bilbao, 1989.

${ }^{6}$ A. AZKÁRATE GARAI-OLAÚN, Elementos de Arqueología cristiana de Vizcaya Altomedieval, in Cuadernos de Sección. Prehistoria y Arqueología, 2, 1984, p. 7-135; ID., Arqueología Cristiana de la Antigüedad Tardía en Álava, Guipúzcoa y Vizcaya, Vitoria, 1988; ID., El eremitismo de época visigótica. Testimonios arqueológicos, in Actas del IV Seminario sobre El Monacato (Codex Aquilarensis no 5), Aguilar de Campoo, 1991, 141-179; I. GARCÍA CAMINO, Arqueología y poblamiento en Bizkaia, siglos VI-XII: la configuración de la sociedad feudal, Bizkaia, 2002.

${ }_{7}$ G. ALCALDE CRESPO, Ermitas rupestres de la provincia de Palencia, Palencia, 1990; ID., Iglesias rupestres. Olleros de Pisuerga y otras de su entorno, León, 2007.

${ }^{8}$ R. RUBIO DÍEZ, Los sepulcros rupestres del Suroeste salmantino: mundo funerario y poblamiento entre la tardoantigüedad y la Alta Edad Media (Memoria de Licenciatura inédita), Salamanca, 2011.

9 A. GONZÁLEZ CORDERO, Los sepulcros excavados en la roca en la provincia de Cáceres, in Los visigodos y su mundo, Madrid, 1988, p. 271-284.

${ }^{10}$ A. GONZÁLEZ BLANCO, Realidad, importancia y función de lo rupestre en la arquitectura funeraria y monacal tardorromana desde el Éufrates hasta el Atlántico. El problema de la Arqueología de los Hipogeos, in J.L Cunchillos, J. M. Galán - J. A. Zamora - Villanueva de Azcona (eds.), Actas del I Congreso Español de Antiguo Oriente Próximo: El Mediterráneo en la Antigüedad. Oriente y Occidente (Sapanu. Publicaciones en Internet II), 1988; ID., La investigación sobre las cuevas, in Antigüedad y Cristianismo, X, 1993, p. 15-40; A. GONZÁLEZ BLANCO - U. ESPINOSA RUIZ - J. M. SÁENZ GONZÁLEZ, La población de La Rioja durante los siglos oscuros (IV-IX), in Berceo, 96, 1979, p. 81-111; T. RAMÍREZ PASCUAL - A. GONZÁLEZ BLANCO, San Martín de Albelda, monasterio y scriptorium en el contexto de un importante complejo rupestre, in J. López Quiroga - A. M. Martínez Tejera (eds.), op. cit. (n. 4), p. 197-217. "R. PUERTAS TRICAS, El eremitismo rupestre en la zona de Nájera, in Actas del IX Congreso Nacional de Arqueología, 419-430 (Valladolid), Zaragoza, 1967, p. 419-430; ID., Iglesias hispánicas (siglos V al VIII). Testimonios literarios, Madrid, 1975; ID., Planimetría de San Millán de Suso, Logroño, 1979; ID., La iglesia rupestre de las Mesas de Villaverde (Ardales, Málaga), in Mainake, 1, 1979, p. 179-216; ID., Un asentamiento mozárabe en la zona de la Alozaina. La necrópolis de los 'Hoyos de los Peñones', Málaga, 1982; ID., Excavaciones arqueológicas en las Mesas de Villaverde (Ardales, Málaga), in Anuario Arqueológico de Andalucía, Sevilla, 1987, p. 478-486; ID., Iglesias rupestres de Málaga, in Actas del II Congreso de Arqueología Medieval Española, I, Madrid, 1987, p. 99152; ID., Exploraciones en iglesias rupestres de Ronda (Caja de Ahorros de Ronda), Málaga, 1988; R. PUERTAS TRICAS, El eremitismo rupestre en la zona de Nájera, in Actas del IX Congreso Nacional de Arqueología, Zaragoza, 1967, 419-430; ID., Iglesias hispánicas (siglos Val VIII). Testimonios literarios, Madrid, 1975; ID., Planimetría de San Millán de Suso, Logroño, 1979; ID., La iglesia rupestre de las Mesas de Villaverde (Ardales, Málaga), in Mainake, 1, 1979, p. 179216; ID., Un asentamiento mozárabe en la zona de la Alozaina. La necrópolis de los 'Hoyos de los Peñones', Málaga, 1982; ID., Excavaciones arqueológicas en las Mesas de Villaverde (Ardales, Málaga), in Anuario Arqueológico de Andalucía, Sevilla, 1987, p. 478-486; ID., Iglesias rupestres de Málaga, in Actas del II Congreso de Arqueología Medieval Española, I, Madrid, 1987, p. 99-152; ID., Exploraciones en iglesias rupestres de Ronda, Málaga, 1988.

${ }^{12}$ M.C. DÍAZ Y DÍAZ, A propósito de la 'Vita Fructuosi', Bibliotheca hagiographica latina 3.194, in Cuadernos de Estudios Gallegos, 25, 1953, p. 155-178; ID., El eremitismo en la España visigoda, in Revista Portuguesa de Historia, VI, 1955, p. 211-237; ID., La vida eremítica en el reino visigodo, in España Eremítica, Actas de la VI Semana de Estudios Monásticos, Pamplona, 1970; ID., La vida de San Fructuoso de Braga. Estudio y edición crítica, Braga, 1974; ID., El monacato fructuosiano y su desarrollo, in El Monacato en la diócesis de Astorga durante la Edad Media, Astorga, 1995, p. 33-48; J. LÓPEZ QUIROGA - J. M. RODRIGUEZ LOVELLE, As sepulturas antropomorfas cavadas na rocha e a sua problemática histórica: unha proposta para o seu estudo, in Larouco, 1 , 1991, p. 61-77; ID., Arqueología del poblamiento en el cuadrante noroeste del conventus bracaraugustano, ss. VIII-X, in Arqueología, 21, 1991, p. 30-36; ID., Una interpretación arqueológica del problema historiográfico de la despoblación y la repoblación del valle del Duero, siglos VIII-X, in Anuario de Estudios Medievales, 21, 1991, p. 3-9; ID., Propuesta de cronología e interpretación histórica de los enterramientos en piedra en Galicia durante la Alta Edad Media (ss.V-XI), in Boletín de Arqueología Medieval, 6, 1992, p. 139- 155; ID., Poblamiento rural en el Noroeste de la Península Ibérica (ss. V-XI). Una introducción al estudio del poblamiento rural entre la antigüedad tardía y la Alta Edad Media en Galicia a través de un análisis micro-regional, in Boletín de Arqueología Medieval, 7, 1993, p. 21-52; ID., Las sepulturas 'olérdolanas': historiografía de un tema y ensayo de cronología, in Actas del Congreso Nacional de Arqueología, 2, Teruel, 1995, p. 425-432; ID., Un modelo de análisis del poblamiento rural en el valle del Duero entre los siglos VIII-X, a partir de un espacio macro-regional: las tierras gallego-portuquesas, in Anuario de Estudios Medievales, 27/2, 1997, p. 687-748; ID., L'habitat dispersé de la Galice et du Nord du Portugal entre le $V^{e}$ et le $X^{e}$ siècle. Essai d'interprétation à partir de l'analyse microrégionale, in B. Cursente (éd.), L'habitat dispersé dans l'Europe médiévale et moderne, Toulouse, 1999, p. 97-119; J. LOPPEZ QUIROGA, El 'final' de la Antigüedad en la 'Gallaecia'. La transformación de las estructuras de poblamiento entre Miño 
In addition, some archaeological excavations of rupestrian structures (Christian cult spaces or funeral areas) have not always had taken into account the complexities of this type of architecture and the interpretations are often too stereotyped and reductionist ${ }^{15}$. In the most part of these studies, rupestrian architecture is focused generally, with particular exceptions ${ }^{16}$, as a process due more to local or regional conditions, and as an expression of an "marginal anomaly" in respect to the traditionally settlement network. Its geographical location, mostly in mountain areas of difficult access, with a complex topography and within the limits of traditional agrarian spaces of farms and habitat (inherent to the Roman settlement system), stills condition the pejorative vision that we have about the rupestrian phenomenon. In the context of research studies of territorial scale, it has recently appreciated the importance of the rupestrian phenomenon in relation to Christian architecture ${ }^{17}$, as well as the housing structures made of wood taking advantage of the rock substrate and the tombs excavated on the rock are linked to the Late Antique and Early Medieval settlement system ${ }^{18}$.

An important question that must be taken into account when speaking on rock architecture is the existence of the rupestrian habitat that we can really define as troglodyte settlements. We can distinguee five geographical areas with this type of settlement in the Iberian Peninsula where are concentrated the most part of the cave dwellings that have been preserved: Andalusia, Aragón, the northern subplateau, Castilla-La Mancha, and the regions of Valencia and Murcia. Many of these cave dwellings continue to be inhabited today. Andalusia undoubtedly represents the main focus of this type of settlements, specially the Granada province with the highest concentration in the Guadix-Baza depression, and to a lesser extent the province of Cadiz. Cave dwellings are also particularly important in Valencia and Murcia provinces.

These caves housing are not always associated with spaces dedicated to Christian cult (hermitages or churches) and, therefore, we cannot establish a systematic relationship between the two. In this sense, is not trivial the fact that, as we have noted, while many caves dwelling are still inhabited today, in the case of churches none of them currently holds Christian cult activity. In respect to the age-long occupational continuity of the caves dwellings there are obvious explanations of socio-economic type; but in the case of the rupestrian churches, his chronological dimension, circumscribed to specific historical moments, is due to other more complex causes ${ }^{19}$.

\section{LATE ANTIQUE AND EARLY MEDIEVAL RUPESTRIAN CHRISTIAN LANDSCAPES IN HISPANIA}

The Vita Fructuosi, wrote by Valerius at the end of the $7^{\text {th }}$ century, is filled with references to a very specific landscape when he describes the spaces where Fructuosus establish their monasteries: forest areas, crags, caves, and almost inaccessible places ${ }^{20}$. Valerius refers also to these landscapes

y Duero (siglos V-X), La Coruña, 2004; ID., Después del 'final de las villae' entre el Miño y el Duero (ss. VII-X): Comunidades 'fructuosianas', hábitat rupestre y 'aldeas', in J. López Quiroga - M. Conceiçâo Lopes - C. Fernández Ochoa (eds.), Formas de ocupación rural en la Gallaecia y en la Lusitania durante la Antigüedad tardía y la Alta Edad Media, Madrid, 2007, p. 219-246; ID., Arqueología del hábitat rural en la Península Ibérica (siglos V-X), Madrid, 2009; ID., Arqueología funeraria de la Península Ibérica (siglos V-X), Madrid, 2010; M. BARROCA, Necrópoles e sepulturas medievais de Entre-Douro-e-Minho: séculos Va XV, Oporto, 1987; ID., Sepulturas escavadas na rocha entre Douro e Minho, in Portvgalia. Nova Série, 31-32, 2010-2011, p. 115-182; M.L. REAL - I.M. FERNANDES - R. TAVARES - P. SA, As covas ermíticas de Sabariz (Vila Fria-Viana do Castelo), in Minia, 5-6, 1982, p. 5-30; A.M. MARTÍNEZ TEJERA, El contraábside en la "arquitectura de repoblación": el grupo castellano-leonés, in Actas del III Curso de Cultura Medieval Repoblación y Reconquista, Madrid, 1993, p. 149-161; ID., De nuevo sobre áreas ceremoniales y espacios arquitectónicos intermedios en los edificios hispanos (ss. IV-X): atrio y pórtico, in Boletín de Arqueología Medieval, 7, 1993, p. 163-215; ID., El Bierzo I: San Pedro de Montes y la ermita de la Santa Cruz, in Historia 16, XXIV, 227, Madrid, 1995, p. 112-117; ID., Los monasterios hispanos (siglos V-VII). Una aproximación a su arquitectura a través de las fuentes literarias, in Arqueología, Paleontología y Etnografía, 4 (I Jornadas Internacionales los Visigodos y su Mundo), Madrid, 1997, p. 115-125; ID., Peñalba de Santiago y las Cuevas del Silencio, in Historia 16, XXII, 265 (mayo), Madrid, 1998, p. 94-99; ID., San Genadio: cenobita, obispo de Astorga y anacoreta (¿865-936?), in Argutorio, VI, 11 (2o Semestre), 2003, p. 20-22; ID., La arquitectura de la comunidad dimmiyyun (siglos IX-X): 'arquitectura del pacto' y 'arquitectura de resistencia', Codex Aqvilarensis 19, Aguilar de Campoo, 2003, p. 48-72; ID., La 'Tebaida Berciana' en tiempos de San Fructuoso (siglo VII), in Argutorio, 12, 2004, p. 43-45; ID., La realidad material de los monasterios y cenobios rupestres hispanos (siglos V-X), in Actas del XIX Seminario de Historia del Monacato: Monjes y monasterios hispanos en la Alta Edad Media, Aguilar de Campoo, 2006, p. 59-98.

${ }^{13}$ I. MARTÍN VISO, Enterramientos, memoria social y paisaje en la edad media: propuestas para un análisis de las tumbas excavadas en roca en el centrooeste de la península ibérica, in Zephyrus, 69, 2012, p. 165-187; ID., Paisajes sagrados, paisajes eclesiásticos: de la necrópolis a la parroquia en el centro de la Península Ibérica, in Reti Medievali Rivista, 13/ 2, 2012, p. 3-45.

${ }^{14}$ I. MARTÍN VISO, Tumbas y sociedades locales en el centro de la Península Ibérica en la Alta Edad Media: el caso de la comarca de Riba Côa (Portugal), in Arqueología y Territorio Medieval, 14, 2007, p. 21-47; ID., Espacios sin Estado. Los territorios occidentales entre el Duero y el Sistema Central (siglos VIII-IX), in I. Martín Viso (ed.), ¿Tiempos oscuros? Territorio y sociedad en el centro de la península ibérica (siglos VII-X), Madrid, 2009, p. 7-135; ID., La organización social de los espacios funerarios altomedievales en los territorios al sur del Duero, in M. Varela, - R. Varela - C. Tente (eds.), Cristãos e Muçulmanos na Idade Média Peninsular. Encontros e Desencontros, Lisboa, 2011, p. 225-238.

${ }^{15}$ Is the case, in our opinion, of some relevant archaeological sites as Ercavica (Cuenca); “El Tolmo de Minateda” (Hellín, Albacete; Tiermes (Soria); Olérdola (Barcelona); Cuyacabras (Burgos); Sabariz (Viana do Castelo, Portugal; Luesia (Zaragoza); San Pedro of Rocas (Esgos, Ourense); or St. Millán of Suso (La Rioja). ${ }^{16}$ M. BARROCA, op. cit. (n. 12); J. LÓPEZ QUIROGA, op. cit. (n. 12); J. LÓPEZ QUIROGA - M. RODRÍGUEZ LOVELLE, op. cit. (n. 12); I. MARTÍN VISO, op. cit. (n. 13); C. LALIENA - J. M. ORTEGA, Arqueología y poblamiento. La cuenca del río Martín en los siglos V-VIII, Zaragoza, 2005; C. LALIENA - J. M. ORTEGA - J. A. BENAVENTE, Los problemas de escala y la escala de los problemas: algunas reflexiones sobre el poblamien- to altomedieval en el Bajo Aragón, in Ph. Senac (ed.), Villes et campagnes de Tarraconaise et d'al-Andalus (VI'-XIe siècle): la transition, Toulouse, 2007, p. $249-262$.

${ }^{17}$ A.M. MARTÍNEZ TEJERA, op. cit. (n. 12); J. LÓPEZ QUIROGA, op. cit. (n. 12).

${ }^{18}$ M. BARROCA, op. cit. (n. 12); J. LÓPEZ QUIROGA, op. cit. (n. 12); J. LÓPEZ QUIROGA - M. RODRÍGUEZ LOVELLE, op. cit. (n. 12); I. MARTÍN VISO, op. cit. (n. 13); J.A. GUTIÉRREZ GONZÁLEZ, Hábitats rupestres altomedievales en la meseta norte y cordillera cantábrica, in Estudios Humanísticos, 12, 1982, p. 20-56; J.A. MOLINA GÓMEZ, Recorrido por la geografía del monacato rupestre hispano. Una interpretación histórica, in Antigüedad y Cristianismo, 1, 23, 2006, p. 649-665.

${ }^{19}$ A. GONZÁLEZ BLANCO, La cronología de las cuevas artificiales, in J. López Quiroga - A.M. Martínez Tejera (eds.), op. cit. (n. 4), p. 18-28.

20 "Loca nemorosa, agris, densissima, aspera et fragosa per speluncas et rupes... remota solitudine in excelsorum montium sinibus" [M.C. DÍAZ Y DÍAZ, op. cit. (op. cit. 12), p. 86 y 88$]$. 


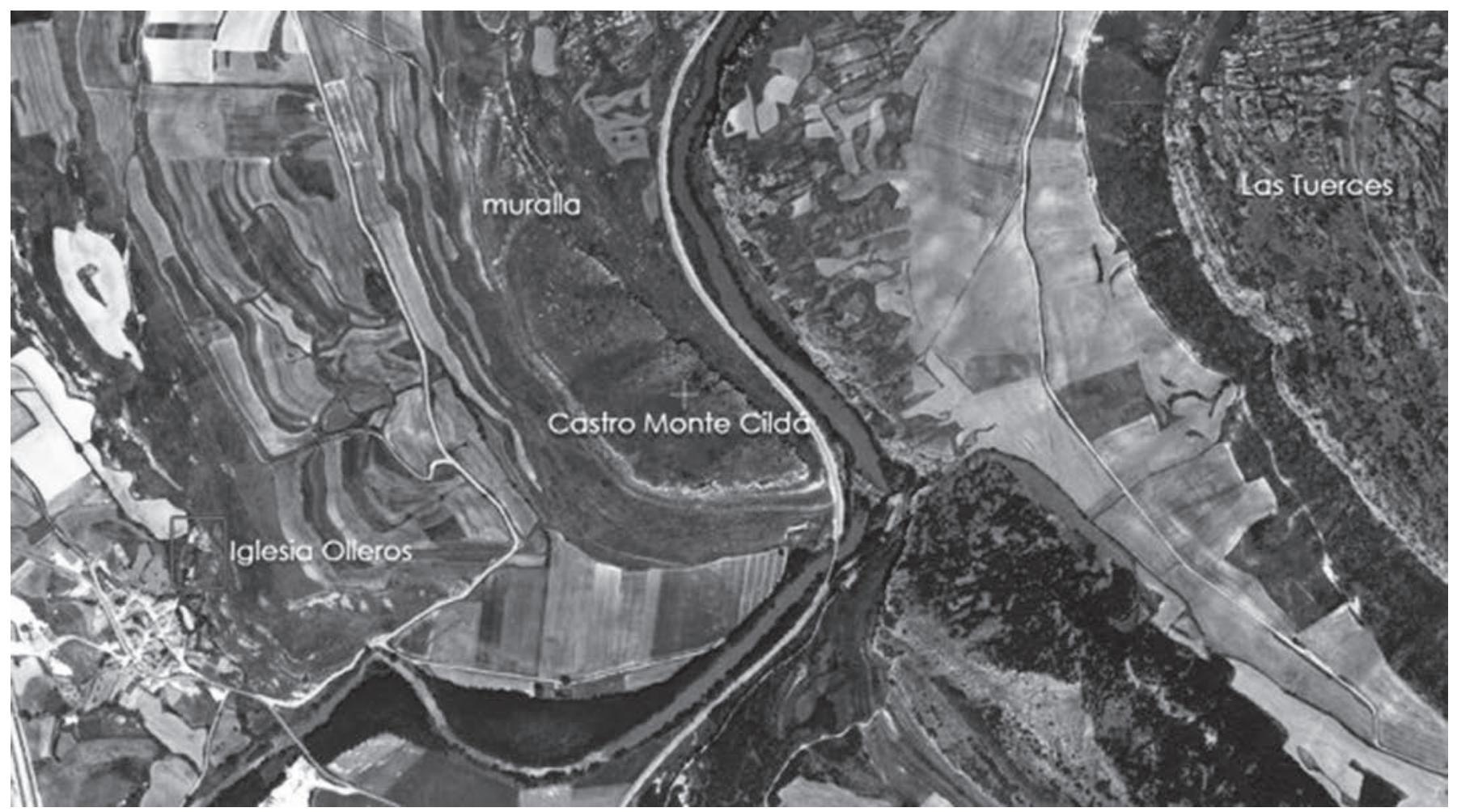

Fig. 1. Situation of the rupestrian church of Olleros de Pisuerga (Palencia) (from Google earth, with modifications of J. López Quiroga).

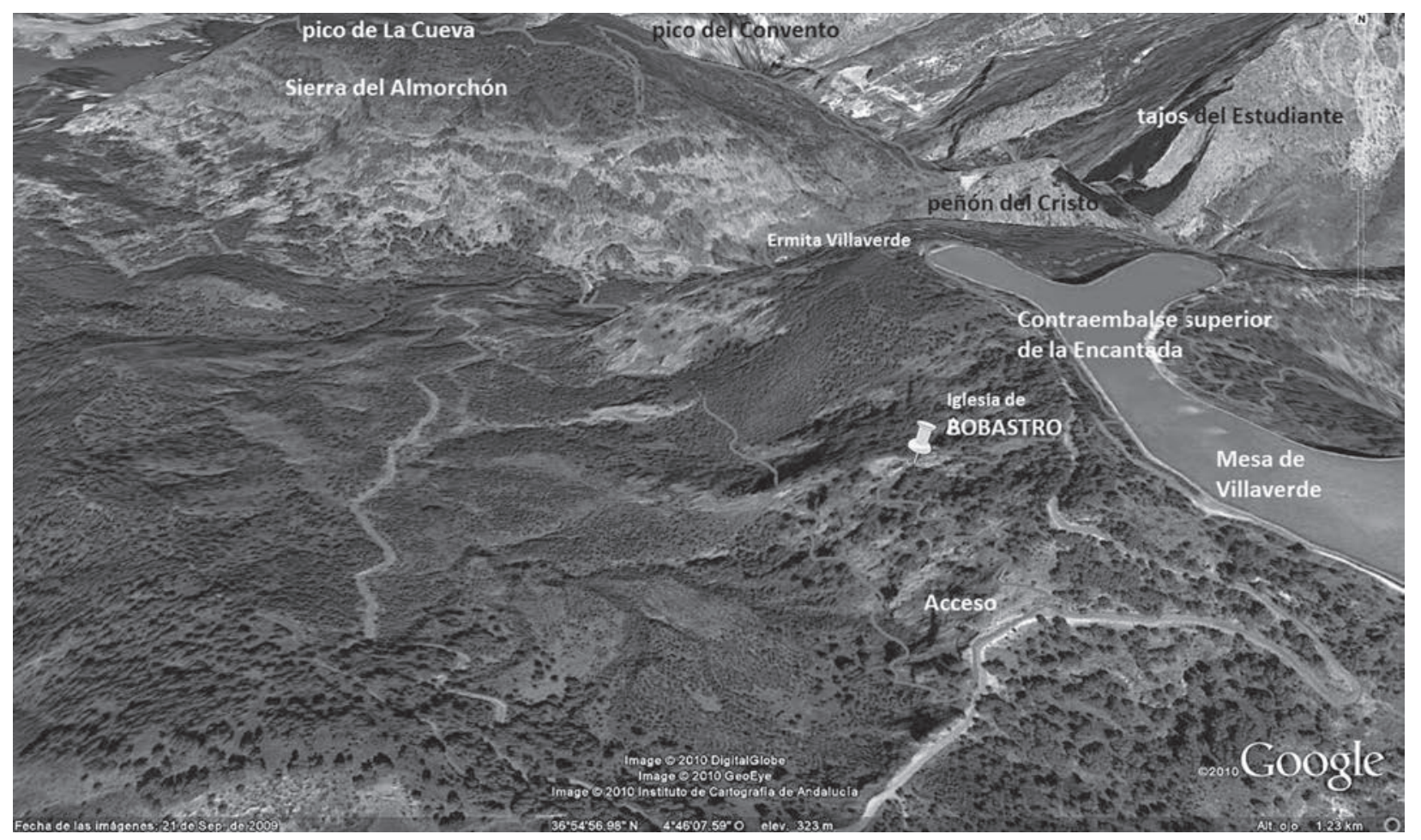

Fig. 2. Situation of the rupestrian complex of Bobastro (Málaga) (from Google earth, with modifications of J. López Quiroga).

speaking about the areas where Fructuosus 'flees' after the founding of the Rufianense monastery, identified with the monastery of St. Pedro de Montes ('El Bierzo', León). This is not the only text, among the few that we have for Hispania (in relation to other European areas, as in France) where we find similar descriptions of the landscapes in which is originates and develops a kind of monasticism traditionally linked with eremitical activities. A similar landscape is described for the Near East (cradle of this type of monasticism) and other broad sectors of the Mediterranean basin, from Late Antique texts. Do late antique authors create a recurring literary topos? Certainly it is not at all, as is well know, a literary figure, neither in the East, nor in the West. Are these landscapes, where rupestrian monasticism develops, the expression of a desire to 'run away' and the need to 'hide'? There is some sort of synonymy between these landscapes and the idea of geographic isolation? Are really these monasteries and hermitages physically isolated from the 'rest of the world'? Is it a geographical reality or a cliché linked with a particular type of Christian spirituality?

Surely, the image of the rupestrian Christian cult complexes as marginal and isolated places is more a historio- 


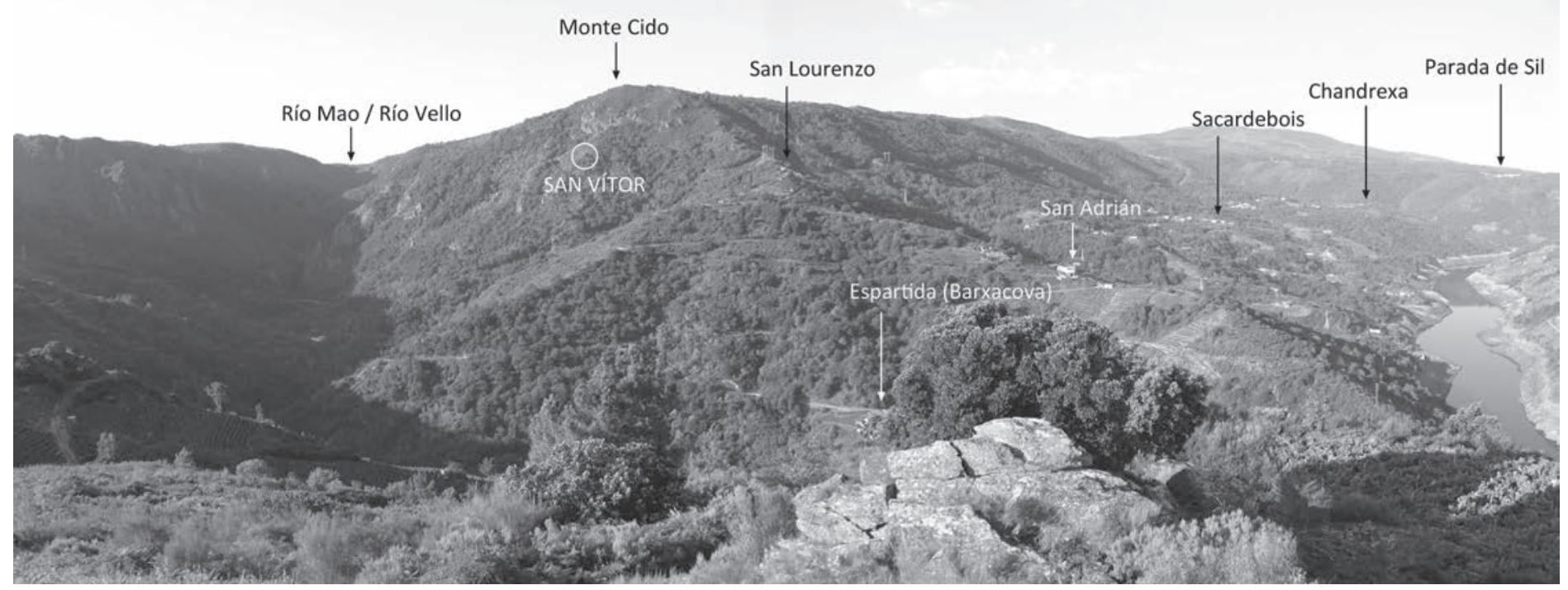

Fig. 3. Situation of the rupestrian complex of St. Vitor (St. Lorenzo da Barxacoba, Ourense) (from Nieto-Muñoz, 2014).

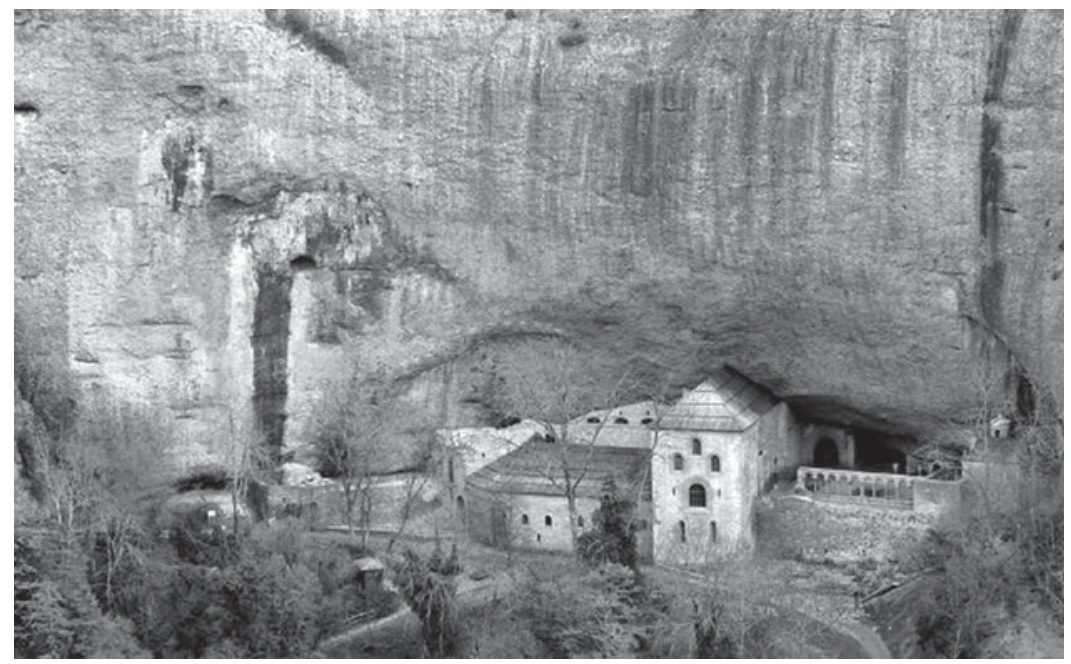

Fig. 4. Rupestrian Monastery of St. Juan de la Peña (Huesca) (C Paisajes Españoles).

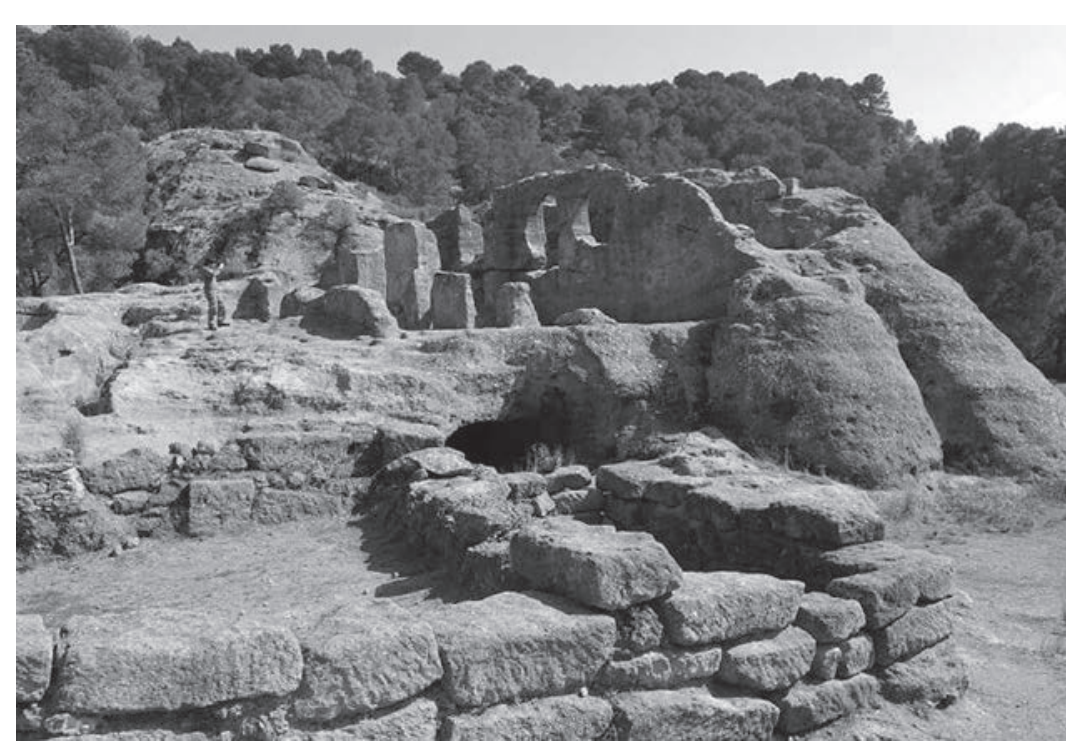

Fig. 6. Rupestrian complex of Bobastro (Málaga) (@ Paisajes Españoles).

graphical topic that a geographical reality. In most cases we are not in the presence of marginal and isolated places, as evidenced in Olleros de Pisuerga (Palencia) (fig. 1), in

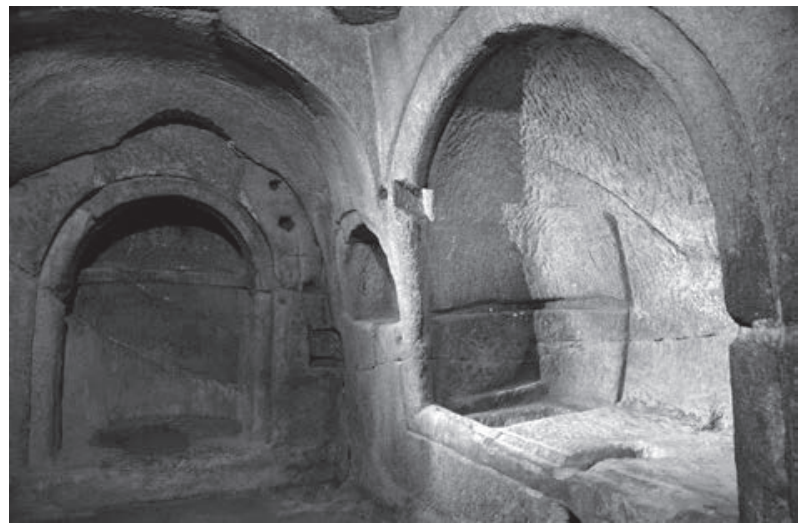

Fig. 5. Interior (right chapel) the rupestrian monastery of St. Pedro de Rocas (Esgos, Ourense) (C) J. López Quiroga).

Bobastro (Málaga) (fig. 2) or in St. Vítor (St. Lorenzo da Barxacoba, Parada do Sil, Ourense) (fig. 3); all of them sites well connected through the road and settlement network. We are conscious of the difficulty to reconciling the analysis of the rupestrian monasticism material reality with the particular spiritual context that characterizes them. But, in our opinion, it is essential to consider the idea and the concept of spirituality representing by the rupestrian monasticism to understand its uniqueness, significance and, of course, its landscape and material contexts. This can help us to understand its historical dimension in their social, economic and even political sphere ${ }^{21}$.

What are these landscapes and materials contexts that define rupestrian monasticism? The typologies of the Christian excavated structures in the Iberian Peninsula, as in most part of Mediterranean basin, are of three types: natural caves (as in St. Juan de la Peña, Huesca: fig. 4), excavated caves (as in St. Pedro de Rocas, Esgos, Ourense: fig. 5) and semi-excavated caves (as in Bobastro, Málaga: fig. 6). The adaptation to cave spaces determines a relatively standardized and highly functional architecture and topography: taking advantage of natural caves as in the late antique laura of "Las Gobas de Laño" (Álava) (fig. 7), in the hermitage of St. Pelayo

${ }^{21}$ J. LÓPEZ QUIROGA - A.M. MARTÍNEZ TEJERA, La edilicia rupestre en la Península Ibérica (siglos VI-XI): Observaciones sobre cuestiones de metodología, interpretación y líneas de investigación, in J. López Quiroga - A.M. Martínez Tejera (eds.), op. cit. (n. 4), p. 6-17. 

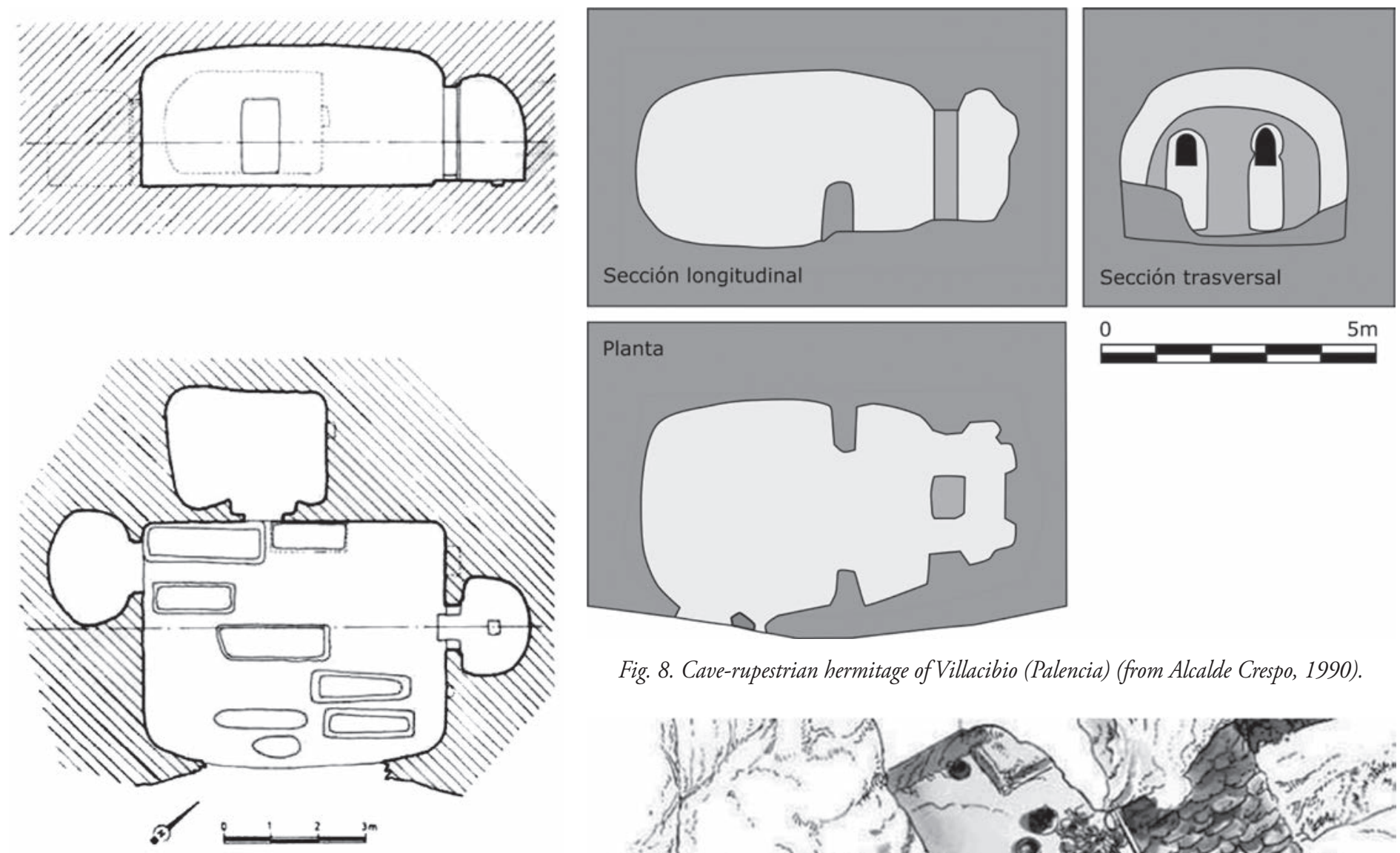

Fig. 7. Cave-rupestrian laura of 'Las Gobas de Laño' (Álava) (from Azkárate, 1988).

in Villacibio (Palencia) (fig. 8) or in Cuyacabras (Burgos) (fig. 9); or of the natural rock structure seeking simple and functional architectural solutions adapted to the celebration of the Christian liturgy as in Bobastro (Málaga) (fig. 10), St. Millán de Suso (La Rioja) (fig. 11), St. Miguel de Bricia (Burgos) (fig. 12) or in St. Pedro de Rocas (Esgos, Ourense) (fig. 13).

All these rupestrian complexes are evidently linked to the Christian cult, but we are over all in the presence of rural settlements and communities. The material reality of these rupestrian spaces shows the existence of living, storage and production areas. Indeed, for the Iberian Peninsula we still have sparse and fragmented information about these housing and productive spaces. Some

Fig. 8. Cave-rupestrian hermitage of Villacibio (Palencia) (from Alcalde Crespo, 1990).

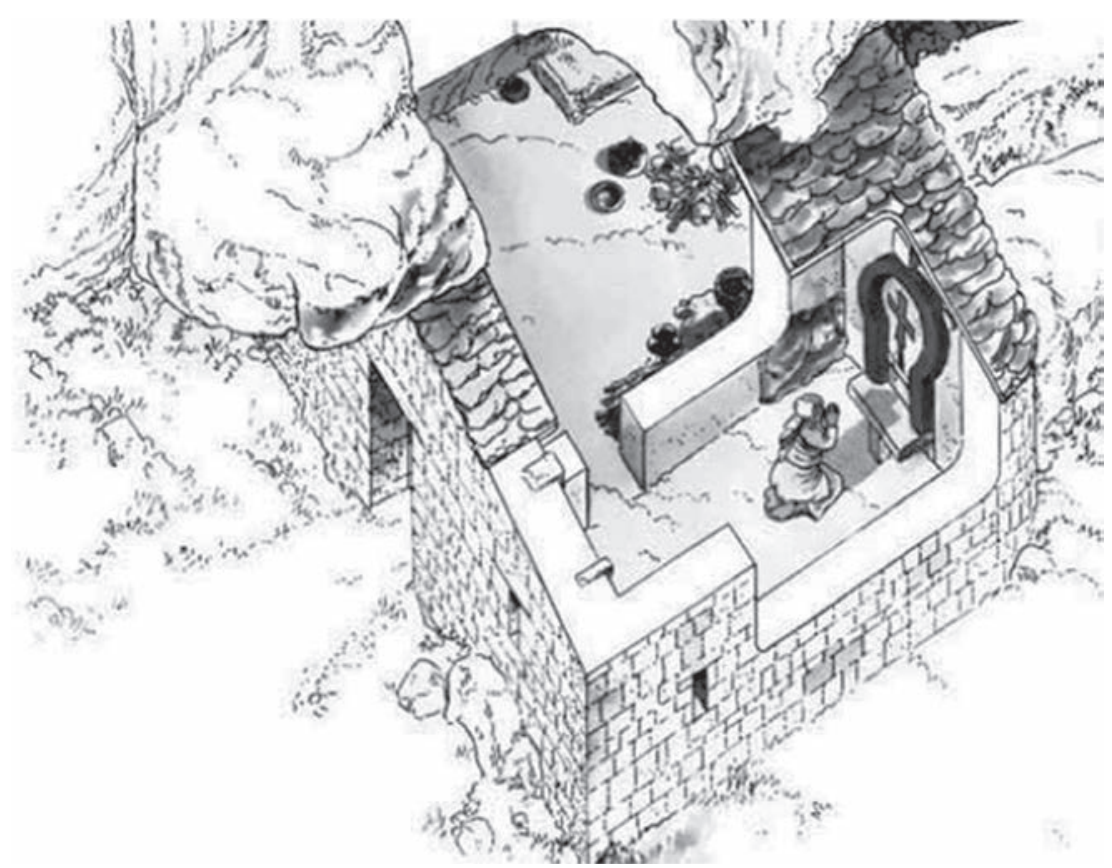

Fig. 9. Rupestrian hermitage of Cuyacabras (Burgos) (from Padilla, 2003). exceptions to this lack of information are the archaeological excavations in "Las Gobas de Laño" (Álava), St. Pantaleón (Puente del Valle, Valderrebible) and the rupestrian complex of Bobastro, (Málaga), which we will discuss later.

"Las Gobas" is a set of thirteen rupestrian cavities, two of them with clear Christian cult functionality, and with tombs excavated in the rock of rectangular and trapezoidal form (fig. 14). The archaeological site excavated by Barandiarán ${ }^{22}$, shows two cult areas ${ }^{23}$ and would be in use, as evidenced by

some graffiti located in situ, from the end of the $6^{\text {th }}$ century until the end of the $7^{\text {th }}$ century ${ }^{24}$. The 'eremitical' character of this group of caves has been recently questioned proposing a reading as "an ecclesiastical centre linked to a possible nearby village" ${ }^{25}$, emphasizing the "peasant initiative" over the "religious character" for this type of settlements. In our opinion, both elements are not only compatibles but also complementary: a rural community configured around a religious complex ${ }^{26}$.

\footnotetext{
$\overline{{ }_{22}}$ J.M. BARANDIARÁN, Excavaciones arqueológicas en grutas artificiales de Álava, in Estudios de Arqueología alavesa, 3, 1968, p. 111-119.

${ }^{23}$ A.M. MARTÍNEZ TEJERA, op. cit. (12), p. 59-98.

${ }^{24}$ A. AZKÁRATE GARAI-OLAÚN, Arqueología Cristiana de la Antigüedad Tardía en Álava, Guipúzcoa y Vizcaya, Vitoria, 1988.

${ }^{25}$ J.A. QUIRÓS CASTILLO, La génesis del paisaje medieval en Álava: la formación de la red aldeana, in Arqueología y territorio medieval, 13, 2006, p. 49-94. ${ }^{26}$ J. LÓPEZ QUIROGA - L. GARCÍA PÉREZ, Las tumbas excavadas en la roca en la Península Ibérica. Tipología, cronología y problemas de interpretación, in J. López Quiroga - A M. Martínez Tejera (eds.), op. cit. (n. 4), p. 36-83.
} 


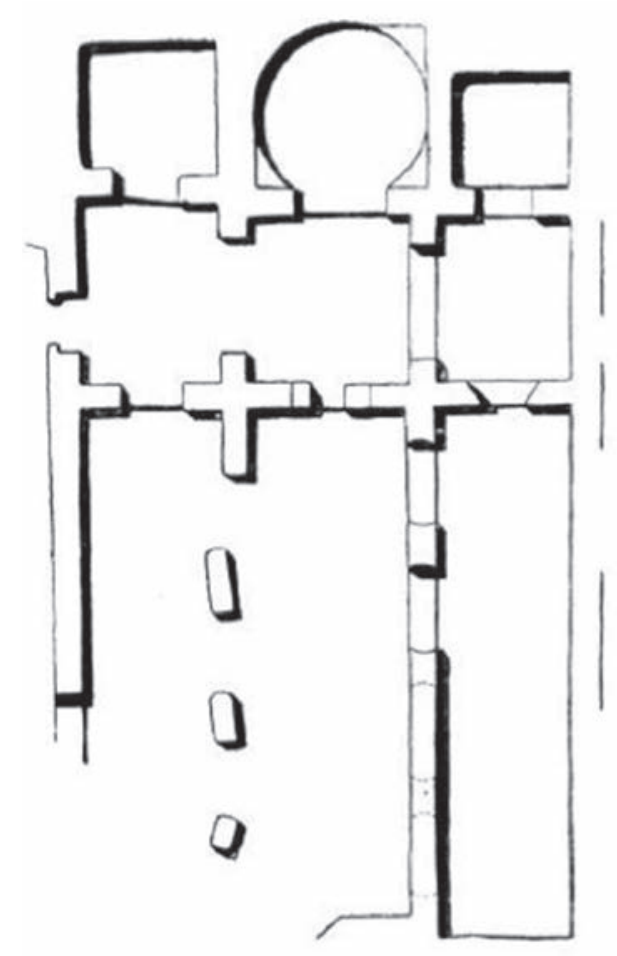

Fig. 10. Rupestrian church of Bobastro (Málaga) (from Puertas Tricas, 1987).

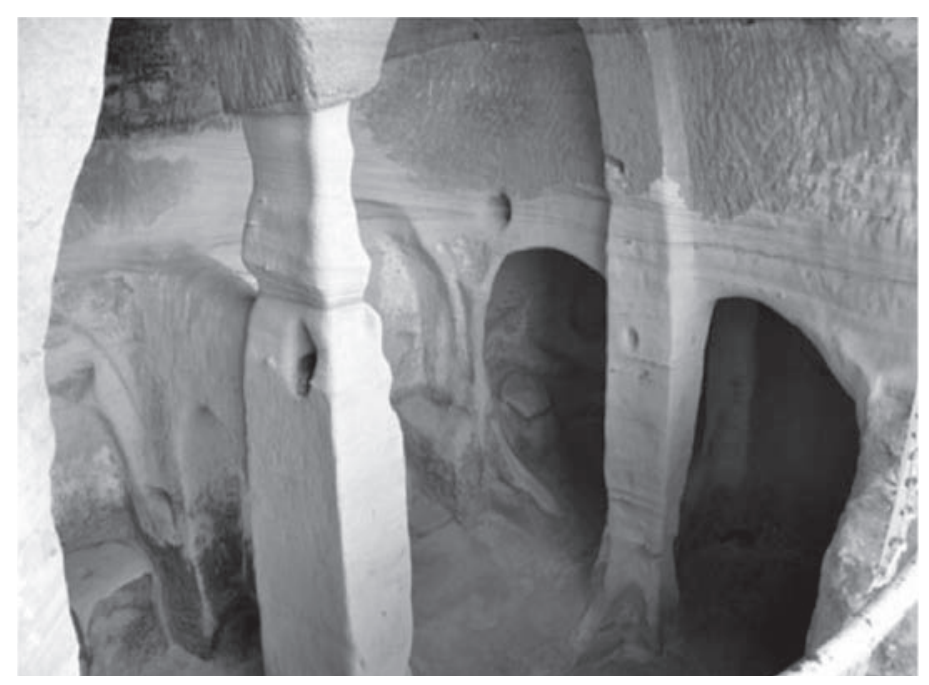

Fig. 12. Rupestrian church of St. Miguel de Bricia (Burgos) (@ Paisajes Españoles).

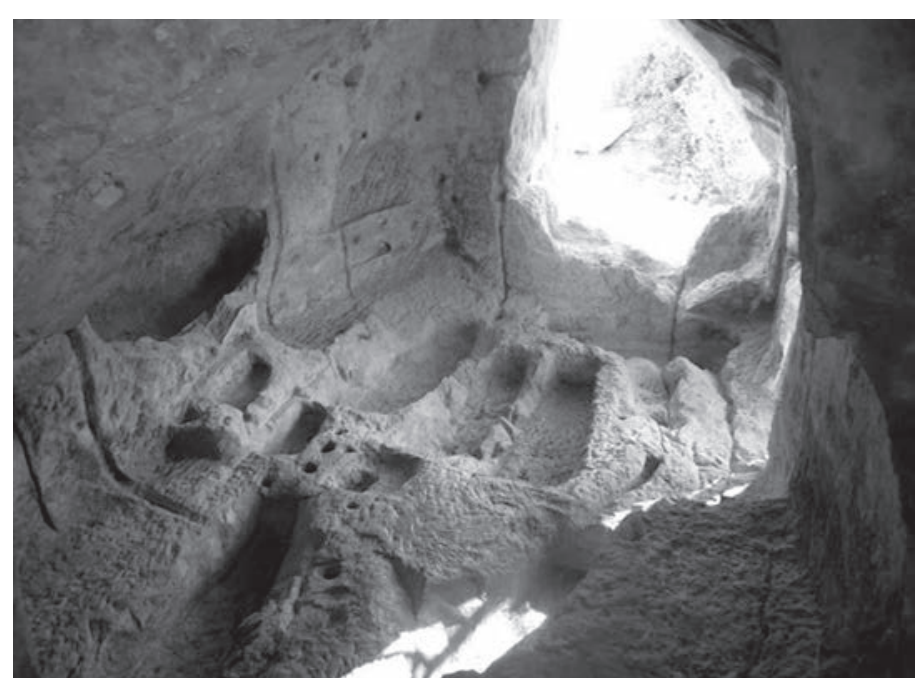

Fig. 14. Interior of the 'Las Gobas de Laño' (Álava) (from Azkárate, 1988).

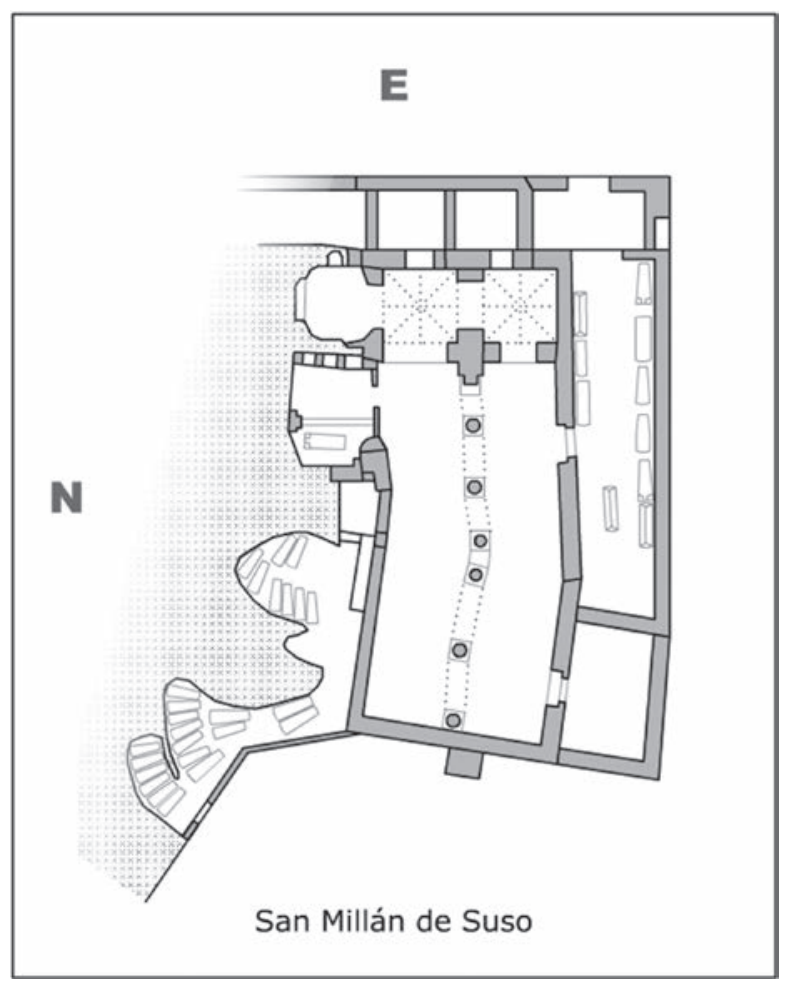

Fig. 11. Rupestrian church of St. Millán de Suso (Logroño) (from Puertas Tricas, 1979).

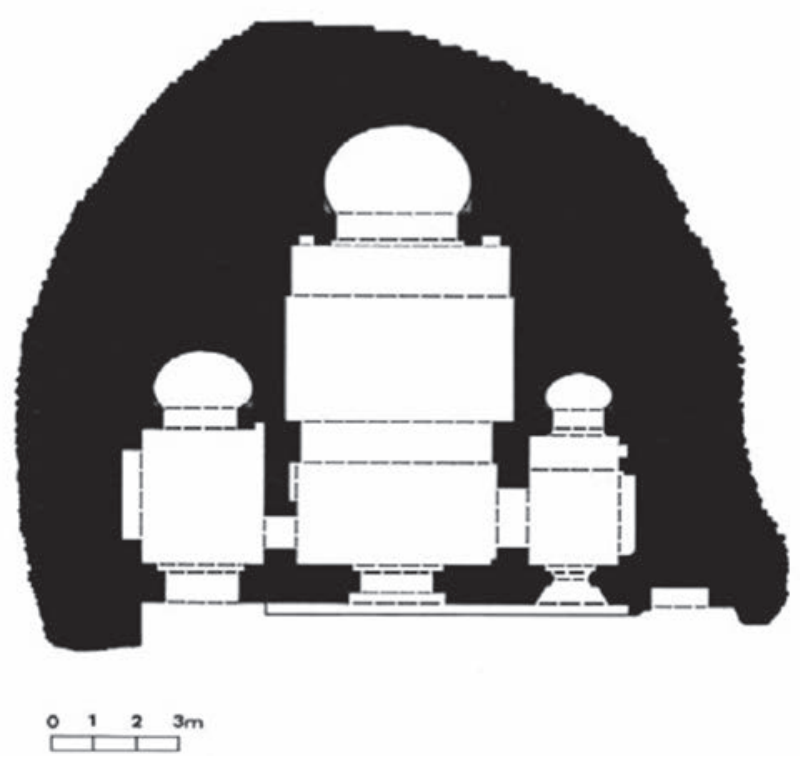

Fig. 13. Rupestrian church of St. Pedro de Rocas (Esgos, Ourense) (from Núnez Rodríguez, 1978).

The archaeological excavations carried out in the summer of 2007 in three of these caves, evidenced an unexpected stratigraphic record of two meters in their interior ${ }^{27}$. In this way, it was possible to identify the complex sequence of the historical events. The beginning of the occupation, which would start sometime in the $7^{\text {th }}$ century, corresponds to the process of extraction that would entail the opening of two artificial cavities. This chronology is supported by the graffiti of "Las Gobas-6" and by the associated ceramic material. In a second moment, an exempt cubicle is constructed, of which has been excavated only a minimal. It is a structure raised at the ground level on thick wooden poles, two of which have been documented through the archaeological excavation. This hut would function as a domestic area, with spaces of diverse use contiguous to the caves: storage (silo type), 


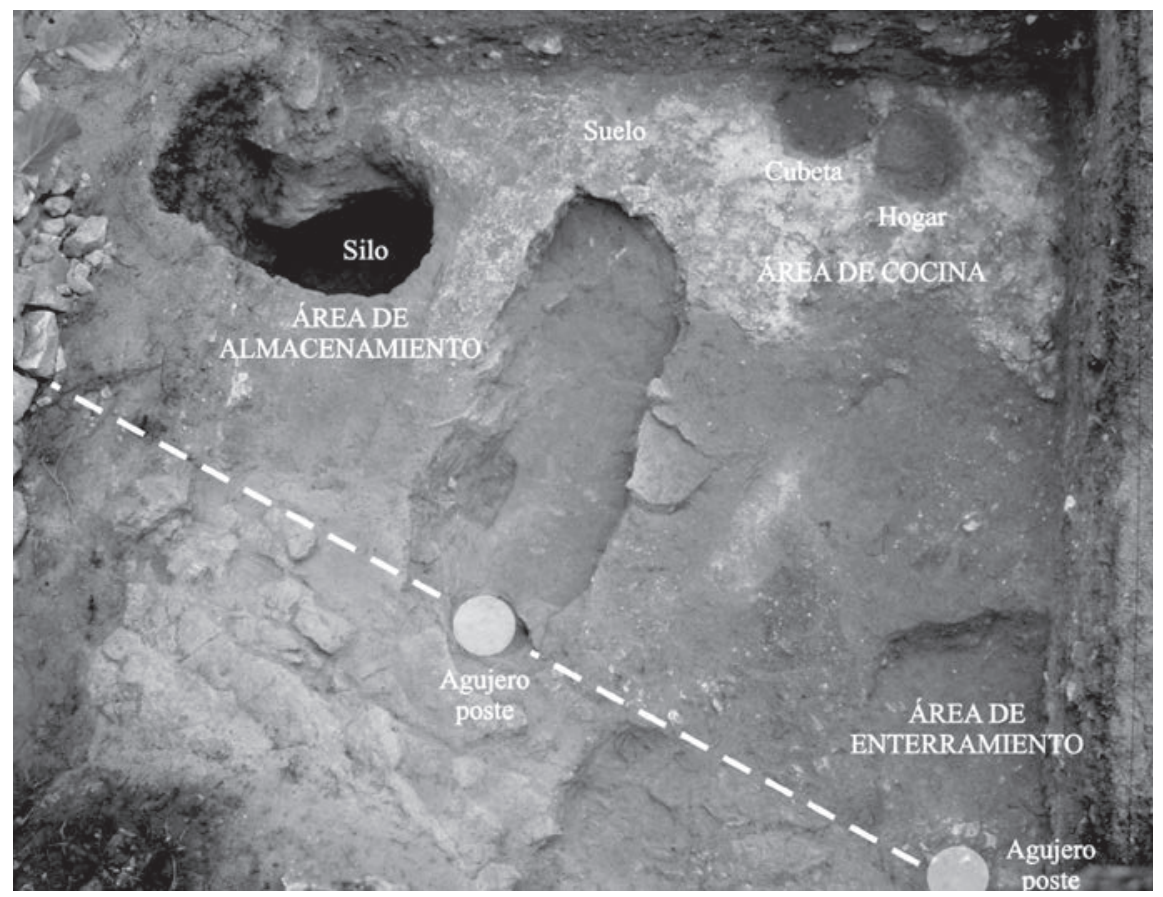

Fig. 15. Domestic, storage and funerary areas of 'Las Gobas de Laño' (Álava) (from AzkárateSolaún, 2008).

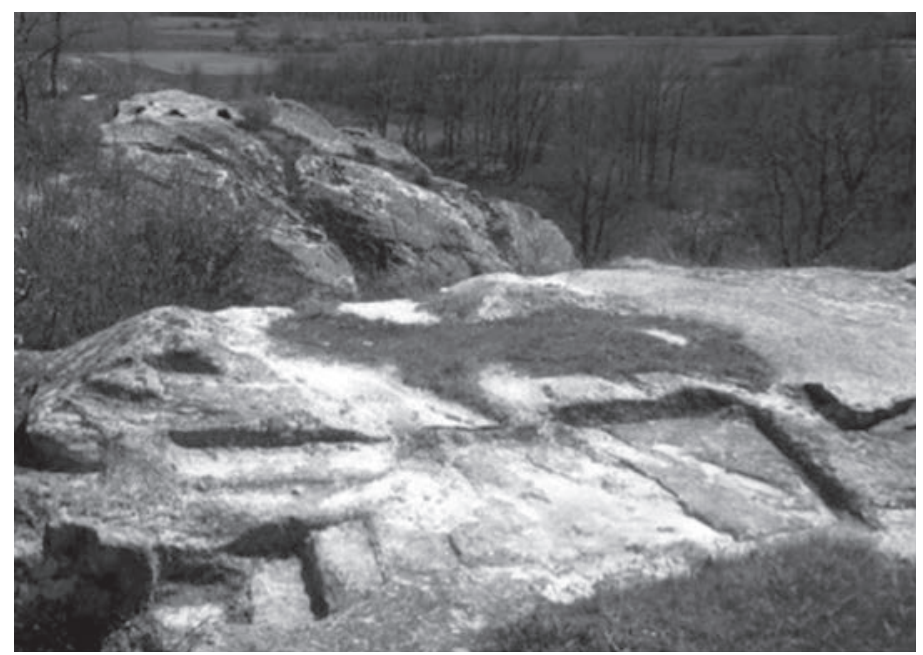

Fig. 16. Rupestrian complex of St. Pantaleón (Valderrebible, Cantabria) (from Fernández González, 2015).

home and funerary (with two burials, one of them a child in a oval pit plant and in supine position, dated by $\mathrm{C}_{14}$ in the last third of the $8^{\text {th }}$ century) (fig. 15). The construction of the cubicle would have been carried out between the $7^{\text {th }}$ and $8^{\text {th }}$ centuries ${ }^{28}$. Between the end of the $8^{\text {th }}$ century and the beginning of the $9^{\text {th }}$, according to the $\mathrm{C}_{14}$ dating, took place a repair of the exempt cubicle, evidenced in the ar- chaeological record by a filling that amortizes both the small funerary space and the two post holes: on the one hand, to an extension of the hut and, on the other hand, to a new soil of sand and clay $^{29}$. In the second half of the $9^{\text {th }}$ century, also from the chronology obtained by the $\mathrm{C}_{14}$ analyses, occurred the abandonment of this space as a habitat place. This is reflected by the sedimentation of the silo, in addition to the presence of a skeleton inside the silo (an adult cow deposited in anatomical connection) and the use of the old storage space as a dump. Finally, during the $10^{\text {th }}$ century, was formed a cemetery area consisting of graves in a rectangular pit with slabs on the sides and on the cover of the tomb. After that no occupational activity was recorded until the $16^{\text {th }}$ century ${ }^{30}$.

The archaeological excavations in "Las Gobas", as well as the various $\mathrm{C}_{14}$ dating obtained, have evidenced the development throughout the $7^{\text {th }}$ century (taking advantage and adapting the various rocky cavities of this place) of a small settlement structured around a Christian cult space with a burial area, of late antique origin, that is defined by a series of tombs excavated in the rock. In the case of St. Pantaleón (La Puente del Valle, Valderrebible) ${ }^{31}$ we have, as for "Las Gobas", C14 dating obtained from samples collected in the filler sediment of four silos attaining a date of $589 \pm 129$ d.C. St. Pantaleón is a complex located on the south bank of the Ebro river, in front of the village of "La Puente del Valle", which offers a very broad chronological sequence, from the recent Prehistory to the Middle Ages. The late antique occupation, linked to the rupestrian church and the annexed cemetery, resulted in a rural settlement of considerable size (fig. 16). The funeral area continued to be used even once the rupestrian church was abandoned, as evidenced by the placement of a small tomb in the southern access stairs. The settlement had at least one forge, showed by the presence of a dump and a possible pottery, actives that remain until the Middle Ages.

Funeral areas, together with church spaces, are generally the most visible and best-known elements of these rupestrian rural settlements. Often, and practically on a majority basis, the burial places are the unique evidence of these rural communities. In this sense, Cuyacabras (Quintanar de la Sierra, Burgos) $)^{32}$ is perhaps, due to the intensive archaeological research performed in that site, one of the most paradigmatic examples of a rupestrian rural community evidenced by the visibility of a big funeral area with a

\footnotetext{
${ }^{27}$ A. AZKÁRATE GARAI-OLAÚN - J.L. SOLAÚN BUSTINZA, Excavaciones arqueológicas en el exterior de los conjuntos rupestres de Las Gobas (Laño, Burgos), in Archivo Español de Arqueología, 81, 2008, p. 133-149.

${ }^{28}$ A. AZKÁRATE GARAI-OLAÚN - J.L. SOLAÚN BUSTINZA, op. cit. (n. 26).

${ }^{29}$ Ibidem.

30 Ibidem.

${ }^{31}$ C. FERNÁNDEZ IBÁÑEZ - P.A. FERNÁNDEZ VEGA - J. PEÑIL MINGUEZ - C. LAMALFA DÍAZ - M A. GONZÁLEZ DE LA TORRE - S. BUSTAMANTE CUESTA, El complejo arqueológico de San Pantaleón (La Puente del Valle, Cantabria). 1 ${ }^{\underline{a}}$ campaña de excavaciones, in Clavis, 3, 1999, p. 41-57; ID., El conjunto arqueológico de época medieval de San Pantaleón (La Puente del Valle, Valderredible) Excavaciones 1998-1999, in Cuadernos de Campoo, 20, 200o, p. 20-28; ID., Avance a la 4 ${ }^{\underline{a}}$ campaña de excavaciones en el conjunto arqueológico de la Peña de San Pantaleón (La Puente del Valle, Cantabria), in Sautuola, IX, 2003, p. 321-341; C. LAMALFA DÍAZ, Excavación del complejo rupestre de San Pantaleón, Puente del Valle (Valderredible). Actuaciones Arqueológicas en Cantabria 1984-1999, Santander, 2000, p. 379-380;

${ }^{32}$ J.I. PADILLA LAPUENTE, Yacimiento arqueológico de Cuyacabras. Despoblado, iglesia y necrópolis. Eremitorio de Cueva Andrés. Quintanar de la Sierra (Burgos), Barcelona, 2002.
} 


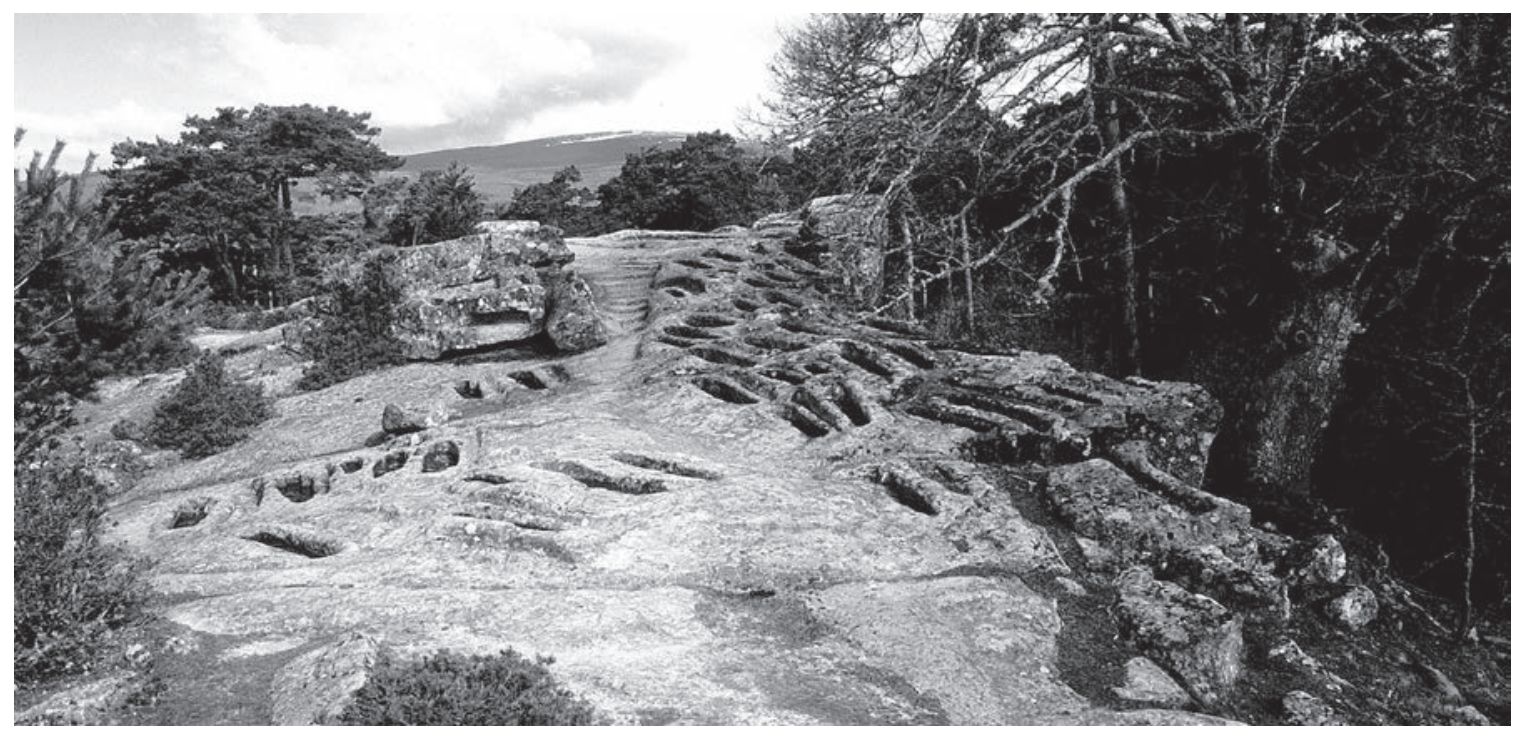

Fig. 17. Rupestrian church and funeral area of Cuyacabras (Burgos) (from Padilla, 2003).

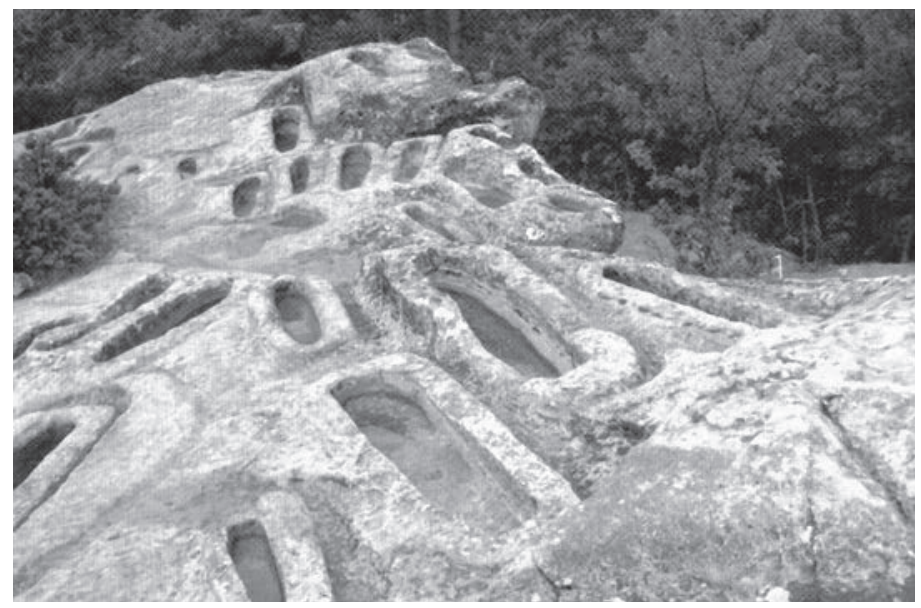

Fig. 19. Different typologies of tombs in Cuyacabras (Burgos) (from Padilla, 2003).

complex typology of burials caved in the rock, associated to a rupestrian church constructed also on the rock (fig. 17). The necropolis, with around 150 graves, was almost entirely excavated by Alberto del Castillo 33 and is considered one of the most big funeral areas (with the well know of Revenga, Regumiel and Duruelo de la Sierra) in the Burgos province. Del Castillo proposes the organization of the funeral space in function of family groupings. In Cuyacabras was found a great staircase excavated in the rock that would serve as access to the church, and around which are the children's tombs. The necropolis now evidences 183 burials, which extending around the church, apparently following a planning in concentric bands that would progressively move away from the sanctuary, concentrating on the higher sectors of the rocky platform (fig. 18). The distribution by age groups in the funeral area offers interesting data, since the total number of graves for children $(29 \%)$ and sub adults $(23 \%)$ exceeds the total number of individuals buried in Cuyacabras (fig. 19). This could be indicating the presence of a high infant mortality for this settlement; however, it is always necessary to be cautious in interpreting these results. Recent archaeological excavations have documented one of the two walls or fences that delimited the funeral area

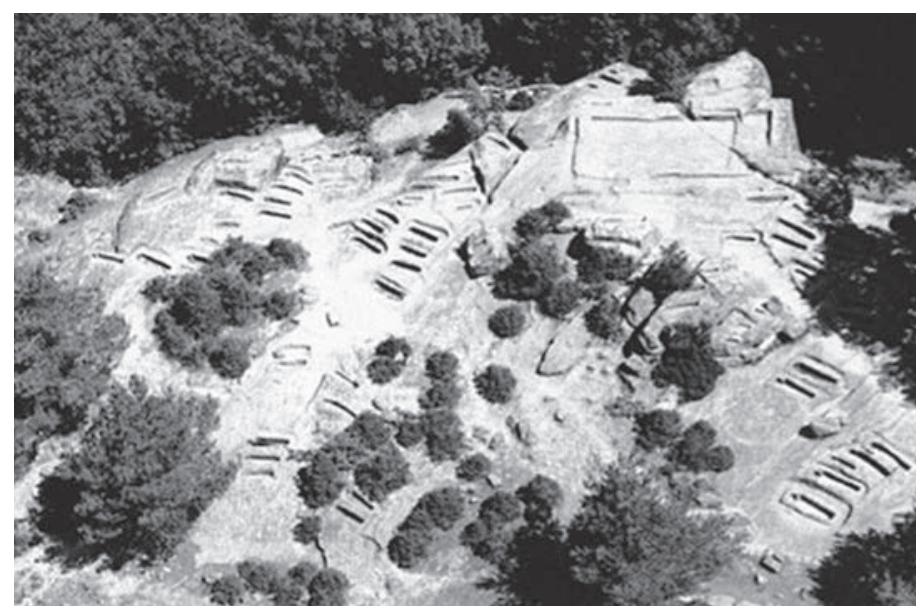

Fig. 18. Areal view of the rupestrian complex of Cuyacabras (Burgos) (from Padilla, 2003).

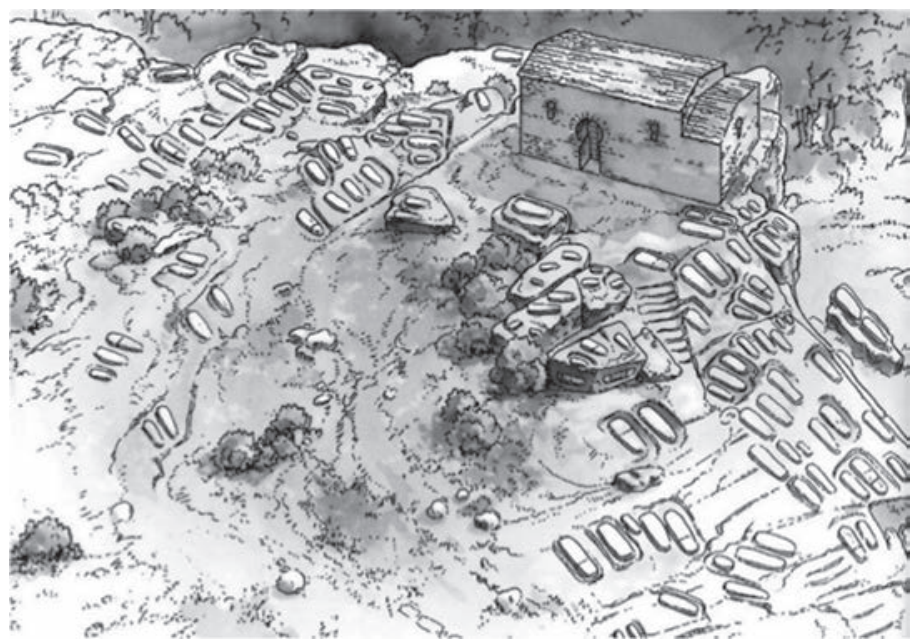

Fig. 20. Distribution of the tombs in respect to the church in Cuyacabras (Burgos) (Padilla 2003).

and that cut several of the graves excavated in the rock. As a criterion for establishing a temporal sequence has been considered the greater or lesser proximity of the burials to the church (fig. 20) ${ }^{34}$. The first phase of the small church (9m

${ }_{33}$ A. DEL CASTILLO, Cronología de las tumbas olerdolanas, in Actas del XI Congreso Nacional de Arqueología, Zaragoza, 1970, p. 835-855; ID., Excavaciones altomedievales en las provincias de Soria, Logroño y Burgos, Madrid, 1972.

${ }^{34}$ I. PADILLA LAPUENTE - F. RIART I JOU, Yacimiento arqueológico de Cuyacabras. Despoblado, iglesia y necrópolis. Eremitorio de Cueva Andrés. Quintanar de la Sierra (Burgos), Barcelona, 2003. 


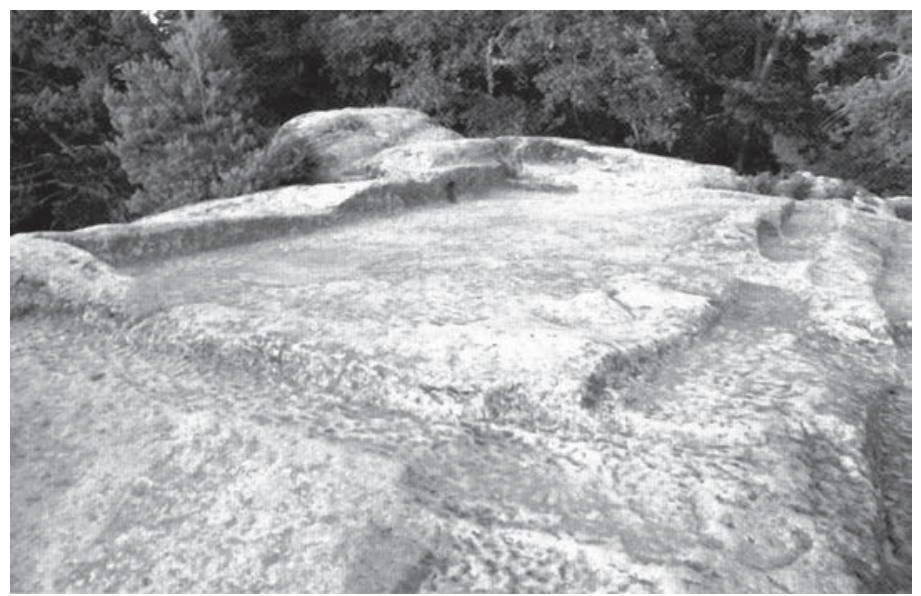

Fig. 21. Rupestrian church excavated on the rock of Cuyacabras (Burgos) (Padilla, 2003).

$\mathrm{x} 4 \mathrm{~m}$ ) forms a structure excavated in the rock that has left its imprint, at the level of foundation, since the rock shelf was cut for this purpose (fig. 21).

Undoubtedly, Cuyacabras is a paradigmatic example of a rural settlement in which a Christian cult place plays a determining role in the configuration and development of the village. Indeed, Cuyacabras is organised as a village settlement (that could perhaps relate to the villa Godomar mentioned in the medieval texts) organized throughout three concentric areas. Firstly, the rupestrian church that, due to its topographic situation, constitutes a central point of reference for the settlement. Secondly, and around the church, we found the funeral area with an extensive necropolis of tombs carved into the rock. Next to the church and burial area would be the houses and economic structures that conform the village. And, thirdly, in a larger space, would be developed the economic activities of the village in close relation with the surrounding forest mass ${ }^{35}$.

There is an evident relationship between the funerary areas with tombs excavated in rock and the settlements in caves in certain areas of the Iberian Peninsula, especially in the north, as in Logroño, Álava, Burgos, Palencia and Santander. Among them, in Albelda, where are know twenty-four Christian cult caves systematically associated, by the most part of researchers, with a "hermit movement" (although this is not always the only plausible interpretation $\left.^{36}\right)$. Also in Andalusia is verified this process: in the "hermitage" of Valdecanales (Jaén); in the cave church and the associated caves of Coín (Málaga) ${ }^{37}$; and in the region of Guadix (Granada).

It is necessary to emphasize that it is practically impossible, from a strictly archaeological perspective, to determine if the Christian cult spaces associated with this funeral areas had or not a hermit character. This term, certainly, can lead to confusion and excessive simplification when interpreting these settlements in which there is a cult factor that is materialized by the existence of spaces dedicated to the Christian liturgy. In fact it is not possible in the current state of the research determine if the origin and development of this rupestrian complexes and settlements were stimulated by an eremitical activity or not ${ }^{38}$.

The religious element, whether it be a laura, hermitage, church or a monastic complex (difficult to determinate, in this case, due to our ignorance about the material reality of the late antique and early medieval monasteries in the Iberian Peninsula), has led to consider the Christian rupestrian complexes as communities composed exclusively of monks; although the presence of children's burials (including newborns, as in the case of St. Pedro de Rocas) ${ }^{39}$ should lead us, at least, to moderate that statement, and to think that we are in the presence of socially more complex and diversified rural communities. The rupestrian Christian complexes in the Iberian Peninsula pose us still unresolved questions (and in many cases not even raised) for the Late Antiquity and the Early Middle Ages. Let us analyse three study cases archaeologically well documented, as paradigmatic examples of our doubts and interrogations.

The first case study brings us to the centre of the Iberian Peninsula, to Ercavica (Cuenca), an ancient Roman city located in the Castilian plateau (fig. 22). Thanks to a text transmitted by Ildefonso of Toledo towards the middle of the $7^{\text {th }}$ century we know that the monk Donato arrived to Ercavica from North Africa in the second half of the $6^{\text {th }}$ century. The text narrates the arrival on the Spanish coasts of the North African abbot Donato and its community fleeing the looting provoked by the Berbers. The North African community was composed of seventy monks, being among their most precious belongings an important cargo of books and codices ${ }^{40}$. Ildefonso of Toledo informs us that abbot Donato was buried in a crypt and that his relics were venerated even in his time ${ }^{41}$. Although Ildefonso does not give any date regarding the arrival of the Donato community,

35 I. PADILLA - K.A. RUEDA, Asentamientos altomedievales y otras manifestaciones rupestres del alto Arlanza, in J. López Quiroga - A.M. Martínez Tejera (eds.), op. cit. (n. 4), p. 224-247.

${ }^{36}$ J. LÓPEZ QUIROGA, El final de la Antigüedad en la Gallaecia: la transformación de las estructuras de poblamiento entre Miño y Duero, A Coruña, 2004; A. MARTÍNEZ TEJERA, op. cit. (n. 6), p. 59-98.

${ }^{37}$ M. Riu, Cuevas-eremitorios y centros cenobíticos rupestres en Andalucía oriental, in Actas del VIII Congreso Internacional de Arqueología Cristiana, Barcelona, 1972, p. 431-443.

${ }^{38}$ J. LÓPEZ QUIROGA, op. cit. (n. 36); J.A. QUIRÓS CASTILLO, op. cit. (n. 25).

39 J. LÓPEZ QUIROGA - L. GARCÍA PÉREZ, Las tumbas excavadas en la roca en la Península Ibérica..., op. cit.

$4^{40}$ R. BARROSO, R.J. MORÍN, La ciudad Arcávica en época visigoda: fuentes literarias y testimonios arqueológicos, in I Congreso de Arqueología Peninsular, Oporto, 1994, p. 229-240.

${ }^{41}$ HILD. DE TOLEDO Vir. Illustr. 3: "Donatus et professione et opere monachus cuiusdam eremitae fertur in Africa extitisse discipulus. Hic uiolentias barbararum gentium imminere conspiciens atque ouilis dissipationem et gregis monachorum pericula pertimescens, ferme cum septuaginta monachis copiosisque librorum codicibus navali uehiculo in Hispaniam commeauit. Cui ab inlustri religiosaque femina Minicea subsidiis ac rerum opibus ministratis, Servitanum monasterium uisus est construxisse. Iste prior in Hispaniam monasticae observantiae usum regulamque dicitur aduexisse. Tam uiuens uirtutum exemplis nobilis quam defunctus memoriae claritate sublimis. Hic et in praesenti luce subsistens et in cripta sepulchri quiescens, signis quisbusdam proditur effulgere salutis, unde et monumentum eius honorabiliter colere perhibentur incolae regionis" (ed. C. Codoñer Merino, El De Viris Illustribus de Ildefonso de Toledo. Estudio y edición crítica, Salamanca, 1972, p.120-123). 


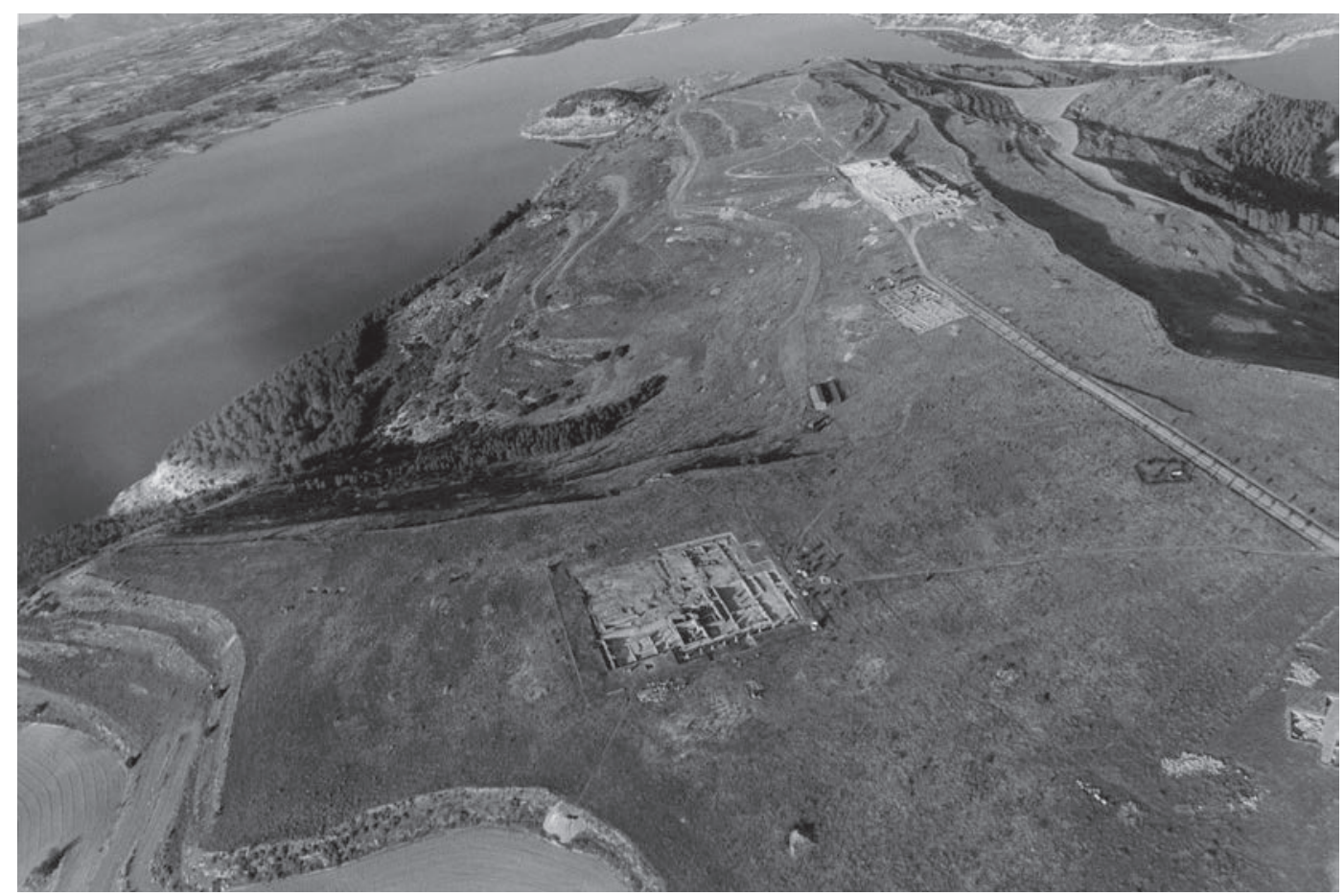

Fig. 22. Aerial view of the roman city of Ercavica (Cuenca) (from Barroso-Carrobles-Diarte-Morin, 2014).

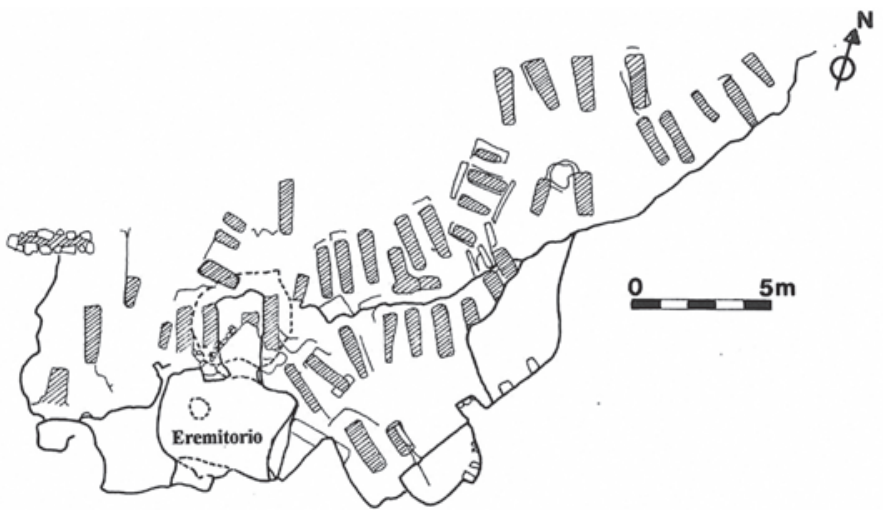

Fig. 23. Rupestrian hermitage and funeral area in the suburbium of Ercavica (Cuenca) (from Barroso-Carrobles-Diarte-Morín, 2014).

the foundation of the Servitano monastery can to be dated in the $571 \mathrm{~A}$. D. thanks to a brief notice of the Chronicle of Jean of Biclaro ${ }^{2}$.

The monastic community of Donato was initially established in the suburbium of the ancient Roman city of Ercavica, around a church carved in the rock, a little construction that served as the first agglutinating nucleus of the community ${ }^{43}$ (fig. 23). The monks would have provisionally settled around this construction as a hermit community organized in laurae ${ }^{44}$. The privileged grave found in the inner chamber of the rupestrian church must belong to the founding father of the community; of whom we know that at his death he was buried in a crypt (in crypt sepulchri qui-

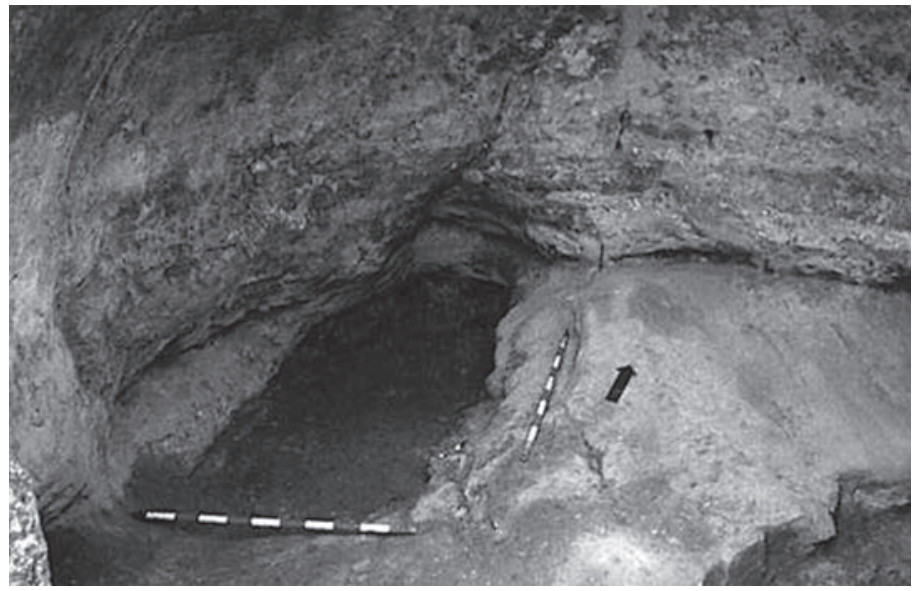

Fig. 24. Privileged grave inside the rupestrian hermitge of Ercavica (Cuenca) (from Barroso-Carrobles-Diarte-Morin, 2014).

escens) (fig. 24). The inhabitants of the place venerated their memory even in the time of Ildefonso, that is to say, almost a century after the arrival of Donato. The fame of sanctity and the miraculous character of the relics of the founder, confirmed by the text of Jean of Biclaro and Ildefonso of Toledo, would have given rise to the birth of the cult of the former abbot Donato ${ }^{45}$. The result of this cult is the creation of an ad sanctos funerary area around the hermitage and the privileged burial. The virtual reconstruction of the hermitage let us to see that the rock was used as building material to construct the hermitage and the funeral area, which take

\footnotetext{
$\overline{4^{2}}$ Ioan. Bicl. Chronica, 571.4: «Donatus, abbas monasterii Servitani mirabilium operator clarus habetur» [ed. J. Campos, Juan de Biclaro, obispo de Gerona. Su vida y su obra, Escuela de Estudios Medievales, XXXII, Madrid, 196o, p. 81].

${ }^{43}$ C. MONCÓ GARCÍA, El eremitorio y la necrópolis hispano visigoda de Ercávica, in I Congreso Arqueología Medieval Española, II, Zaragoza, 1986, p. $241-257$. ${ }^{44}$ C. MONCÓ GARCÍA, op. cit. (n. 43); A.M. MARTÍNEZ TEJERA, op. cit. (n. 12); J. LÓPEZ QUIROGA, Monasterios altomedievales hispanos: lugares de emplazamiento y ordenación de sus espacios, in J.A. García de Cortazar - R. Teja (eds.), Los monasterios medievales en sus emplazamientos: lugares de memoria de lo sagrado (XXIX Seminario sobre Historia del Monacato), Aguilar de Campoo, 2016, p. 66-99.

45 IOAN. BICL. Chron. 571, 4: «Donatus, abbas monasterii Seruitani mirabilium operator clarus habetur»; HILD. TOL. Vir. Illustr. 3: «Hic et in praesenti luce subsistens et in cripta sepulchri quiescens, signis quisbusdam proditur effulgere salutis, unde et monumentum eius honorabiliter colere perhibentur incolae regionis».
} 


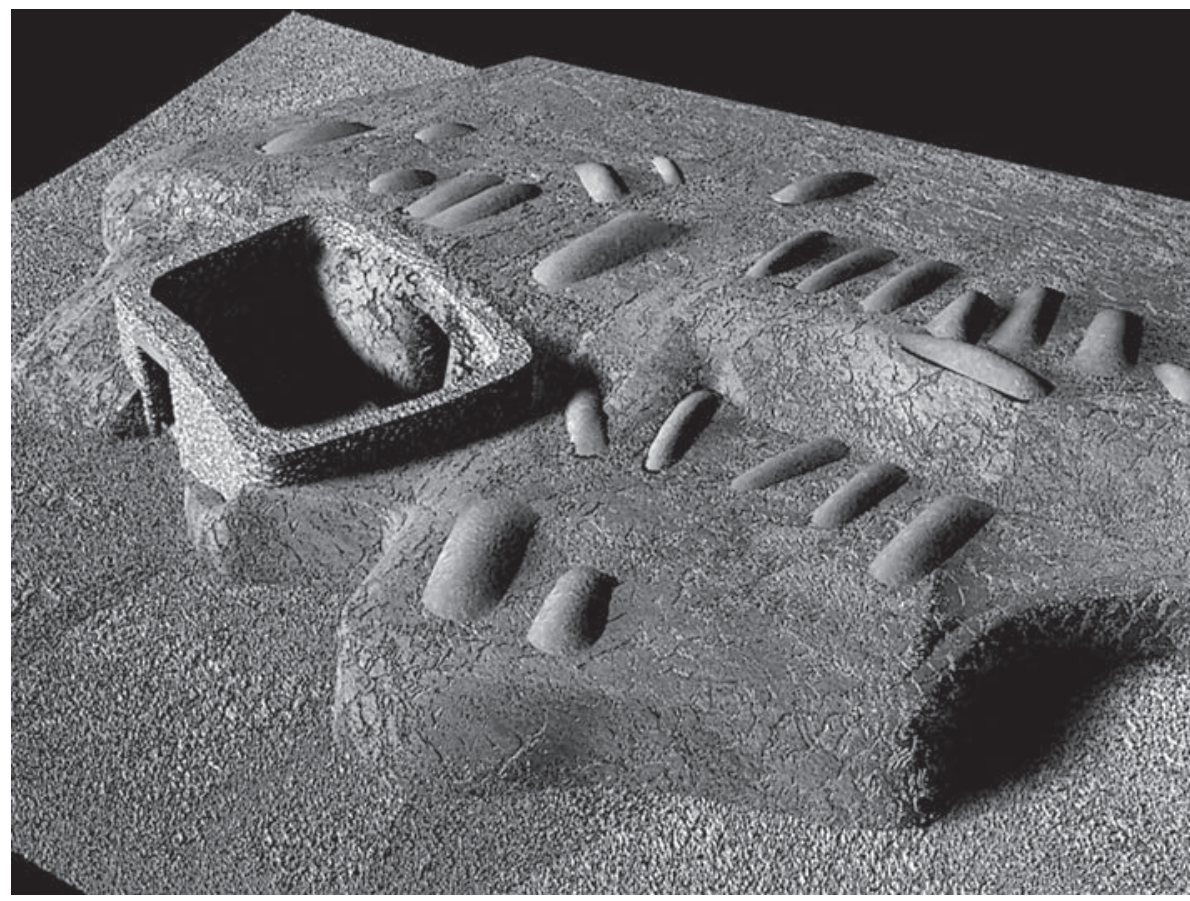

Fig. 25. Virtual reconstruction of the rupestrian hermitage and funeral area of Ercavica (Cuenca) (from Barroso-Carrobles-Diarte-Morín, 2014).
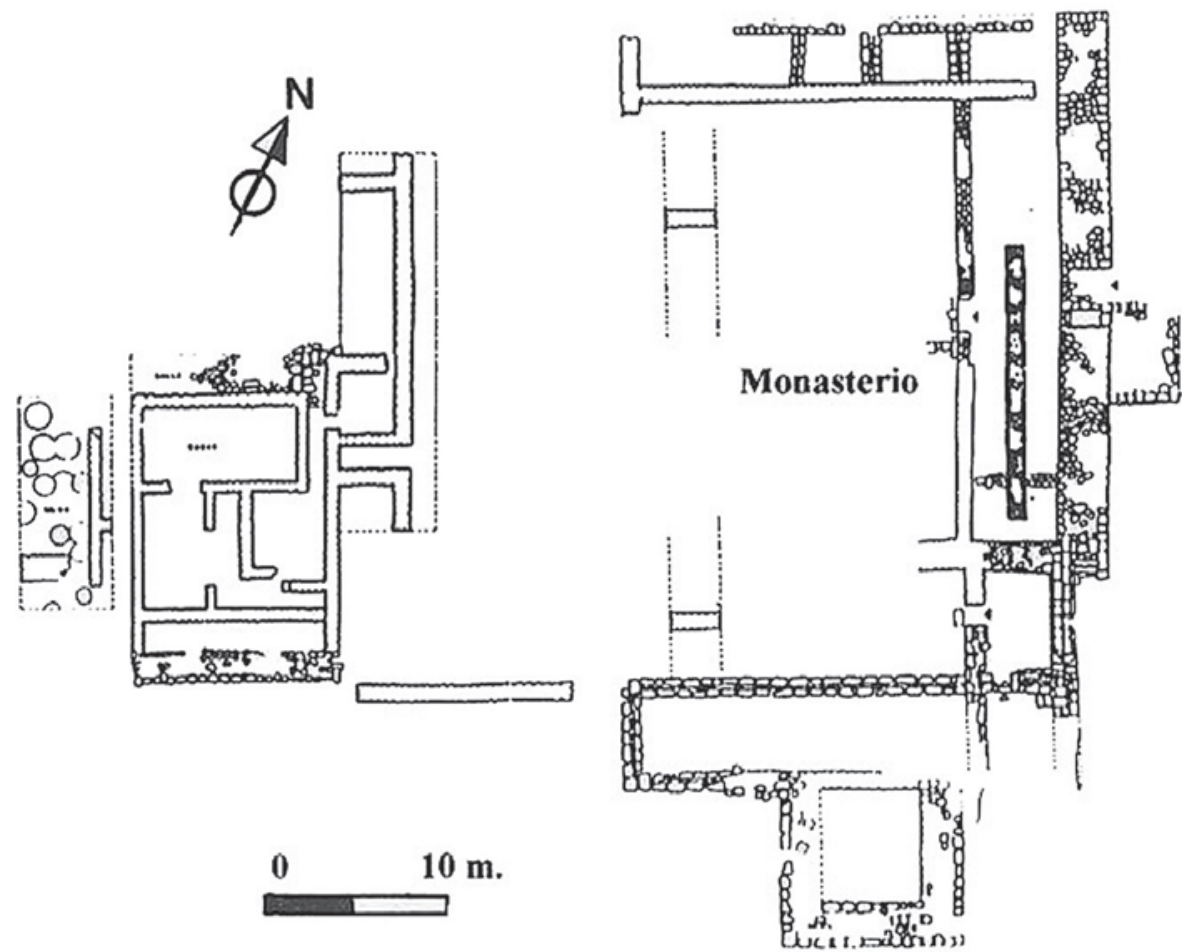

Fig. 26. Servitano monastery built in the suburbium of Ercavica (Cuenca) (from Barroso-CarroblesDiarte-Morin, 2014).

advantage of the entire rocky promontory around the small cult construction ${ }^{46}$ (fig. 25).

A few meters away (but always in the suburbium of the ancient roman city) the archaeological excavations seems

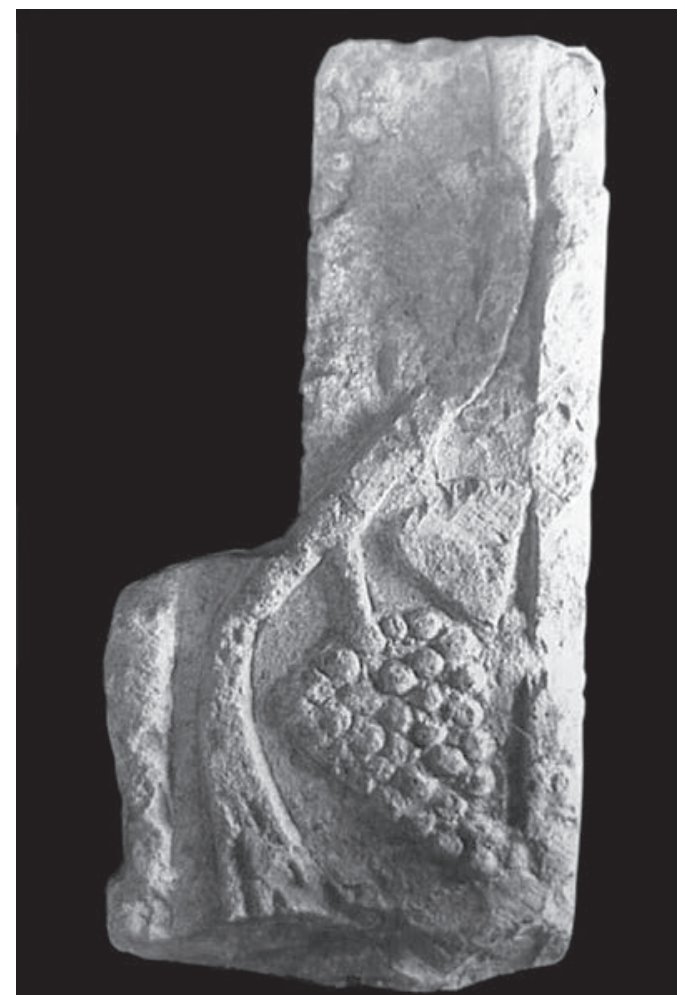

Fig. 27. Fragment of a decorated pilaster found in the excavations of the Servitano monastery (from BarrosoCarrobles-Diarte-Morin, 2014).

to have evidenced the ruins of the Servitano monastery built in the late $6^{\text {th }}$ century in the lands donated by a noble Gothic female called Minicea (fig. 26); we must not forget that the royal city of Recopolis is not far away from Ercavica ${ }^{47}$. The archaeological excavations have uncovered an impressive building on a substructure of reused materials of the ancient Roman city of Ercavica that occupies an area of $50 \mathrm{~m} \times 45 \mathrm{~m}$. The structure of the walls of this construction is considerable (between one and two meters thick) and has been erected with stones, mortar and earth. The successive archaeological excavation campaigns carried out in this place have allowed to identify three well differentiated areas $^{48}$ : a rectangular structure, used as a church in the time of the so-called Repoblación; a rectangular room, interpreted as the cella or storeroom of the "mozarabic" monastery, from which a good lot of containers that preserved its carbonized content (nuts, rye, wheat and almonds), as well as other domestic utensils. Finally we must mention a series of enclosures of $3 \times 3 \mathrm{~m}$; which appear to surround a central structure and interpreted as monastic cells. This distribution suggests a monastery with a centralized plant or at least a

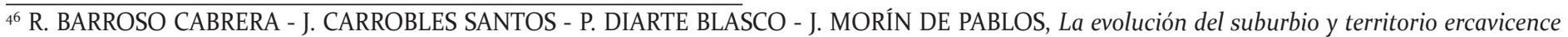
desde la tardía-antigüedad a la época hispano-visigoda. El monasterio Servitano y Recopolis, in J. López Quiroga - A. M. Martínez Tejera (eds.), op. cit. (n. 47), p. 257-298.

${ }^{47}$ R. BARROSO CABRERA - J. MORÍN DE PABLOS, Las ciudades de Arcávica y Recópolis y la fundación del monasterio Servitano. Organización territorial de un asentamiento monástico en la España visigoda, in J. López Quiroga - A.M. Martínez Tejera - J. Morín de Pablos (eds.), Monasteria et territoria. Élites, edilicia y territorio en el Mediterráneo Medieval, in J. López Quiroga - A.M. Martínez Tejera - J. Morín De Pablos (eds.), Oxford, 2007 , p. $233-258$.

${ }_{48}^{8}$ R. BARROSO CABRERA - J. MORÍN DE PABLOS, La ciudad de Arcávica y la fundación del monasterio Servitano, Hispania Sacra 48, 1996, 149-196. 
certain regulated organization (fig. 26). The excavations have also provided some materials that can be dated around the $7^{\text {th }}$ century, including a fragment of pilaster decorated with a rippled stalk filled with vine clusters and a belt clasp ${ }^{49}$ (fig. 27). Ceramics, however, belong to the later "mozarabic" occupation in the $9^{\text {th }}$ century. In addition, the archaeological record has documented a violent destruction of the building towards the middle of the $9^{\text {th }}$ century, destruction that is perceived by the remains of a great fire and the abandonment of the food stored in the cella. The desertion of the building has been linked to the destruction of the "mozarabic" community and the bishop's flight to the royal court of Oviedo in the middle of the $9^{\text {th }}$ century ${ }^{50}$.

Despite having a rigorous and complete archaeological documentation, many are the question raised by Donato and the Servitano monastery built in the suburbium of Ercavica: Why could Donato install his hermitage in the suburbium of a roman city? The lands where Donato built their hermitage, belonging also to the noble gothic Minicea? Were these lands granted to Donato to built a hermitage or the Servitano monastery? Is there a synchronous or diachronic relationship between the small and simple hermitage built by Donato in the $6^{\text {th }}$ century with the monumental Servitano monastery constructed in the late $7^{\text {th }}$ century?

The second case study takes us to the northwest end of the Iberian Peninsula, to St. Vítor (St. Lorenzo da Barxacoba, Parada do Sil, Ourense) in the lands of the ancient roman province of Gallaecia. In the surroundings of the modern village have been carried recently several archaeological campaigns in a place where was only visible some anthropomorphic tombs carved in the rock ${ }^{51}$. St.

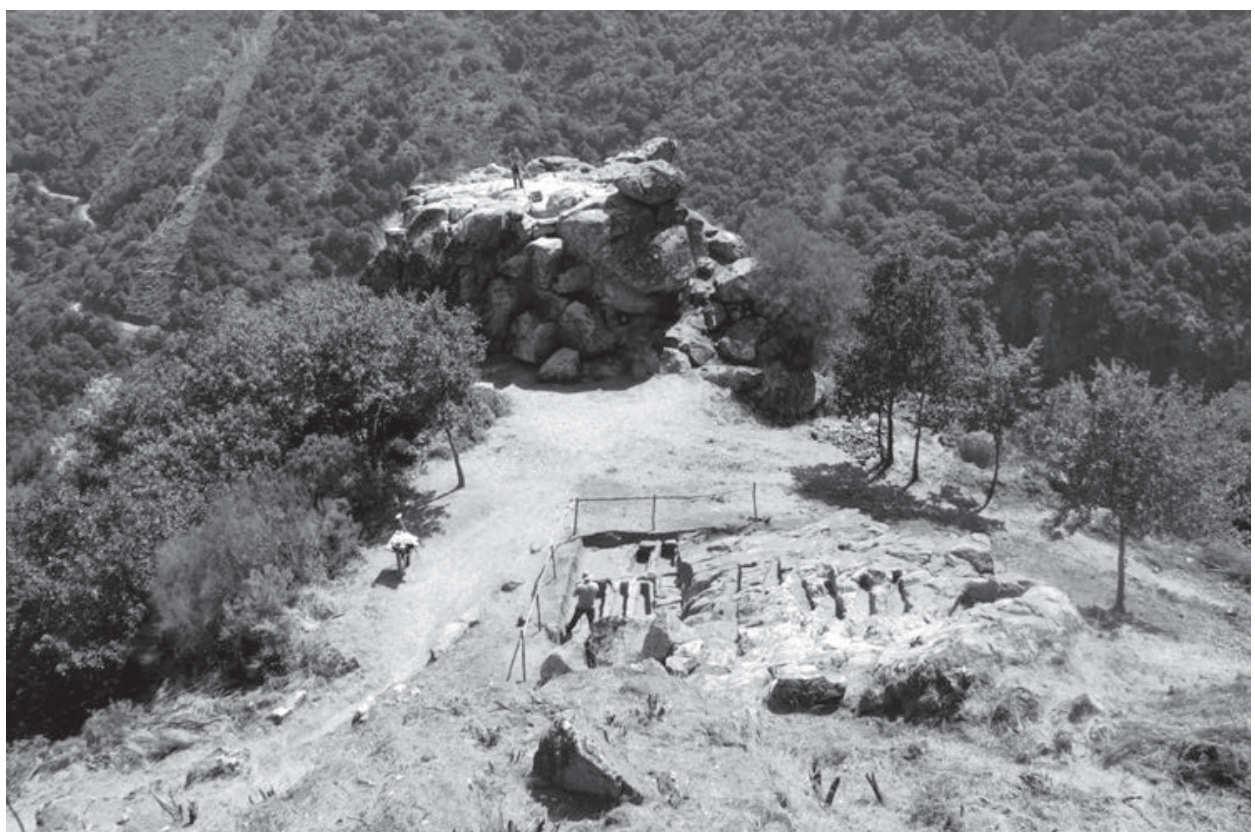

Fig. 28. Aerial view of the rupestrian hermitage and funeral area of St. Vitor (St. Lorenzo da Barxacoba, Parada de Sil, Ourense) (from Nieto-Muñiz, 2014).

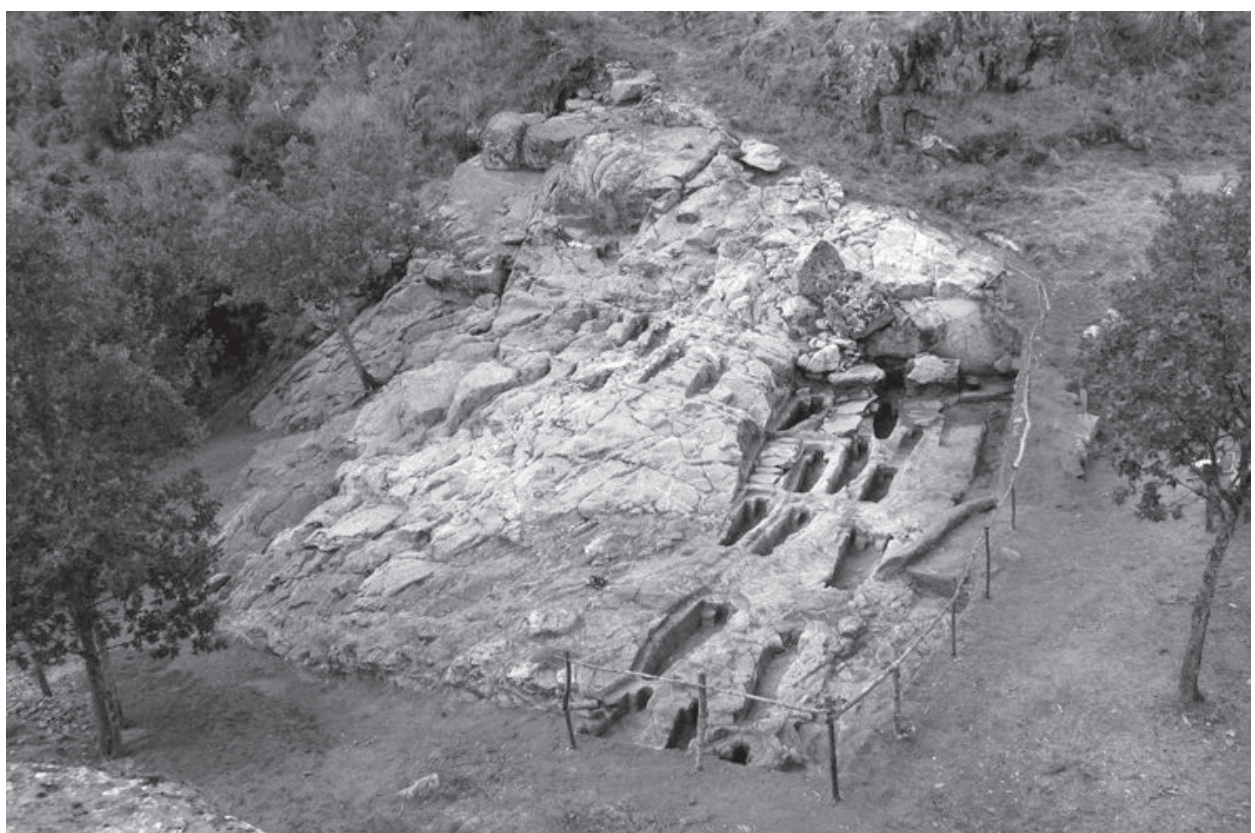

Fig. 29. Aerial view of the funeral area of St. Vitor (St. Lorenzo da Barxacoba, Parada de Sil, Ourense) (from Nieto-Muñiz, 2014).

small rocky promontory have evidenced the existence of an early medieval chapel with four tombs, which seems to manage a collective funeral area developed in the esplanade (figs. 29 and 30) ${ }^{53}$. At least, the presence of a sort of balcony overlooking the esplanade seems to have something to do with the large funeral area developed at the foot of it (figs. 31 and 32). Less unexpected is the presence of a privileged

\footnotetext{
${ }_{49}$ R. BARROSO CABRERA et alii, op. cit. (n. 46).

${ }^{50}$ Ibidem. The date is provided by the appearance of a dirham of 252-262 H / 866-876 A.D.

${ }^{51}$ J. ARIAS SANJURJO, Una excursión a la Ribera Sagrada, in Boletín de la Comisión Provincial de Monumentos históricos y artísticos de Orense, V, 98, Ourense, 1914, p. 49-52; X.C. RIVAS FERNÁNDEZ, Vestigios perrománicos de algunos olvidados monasterios y eremitorios orensanos, in Boletín Auriense, XI, Ourense, 1981, p. 49-100.

${ }_{52}$ X.C. RIVAS FERNÁNDEZ, op. cit. (n. 58); J. LÓPEZ QUIROGA - M. RODRÍGUEZ LOVELLE, Aux origines monastiques de la Galice intérieure (Ve-Xe s.), in Histoire Médiévale et Archéologie, 5, 1992, p. 265-271; J. LÓPEZ QUIROGA, op.cit. (n. 36).

${ }_{33}$ E.B. NIETO MUÑIZ - V. RODRÍGUEZ MUÑIZ, A necrópole rupestre de San Vítor (San Lourenzo de Barxacova, Parada de Sil, Ourense): ¿Grandes necrópoles en lugares desertos?, in J. López Quiroga - A. M. Martínez Tejera (eds.), op. cit. (n. 4), p. 84-116.
} 


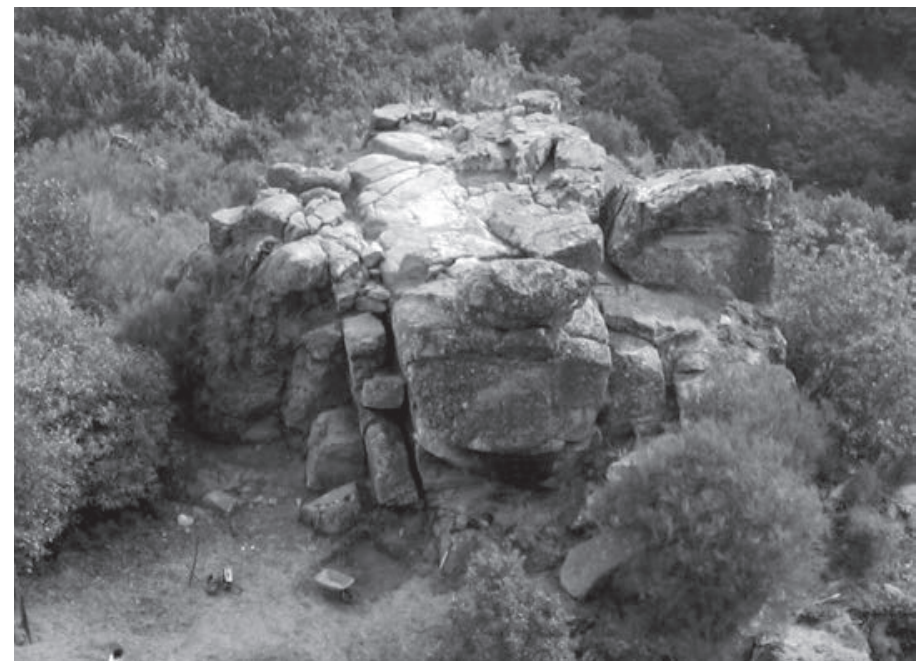

Fig. 30. Aerial view of the rocky promontory where was constructed the rupestrian hermitage of St. Vitor (St. Lorenzo da Barxacoba, Parada de Sil, Ourense) (from Nieto-Muñiz, 2014).

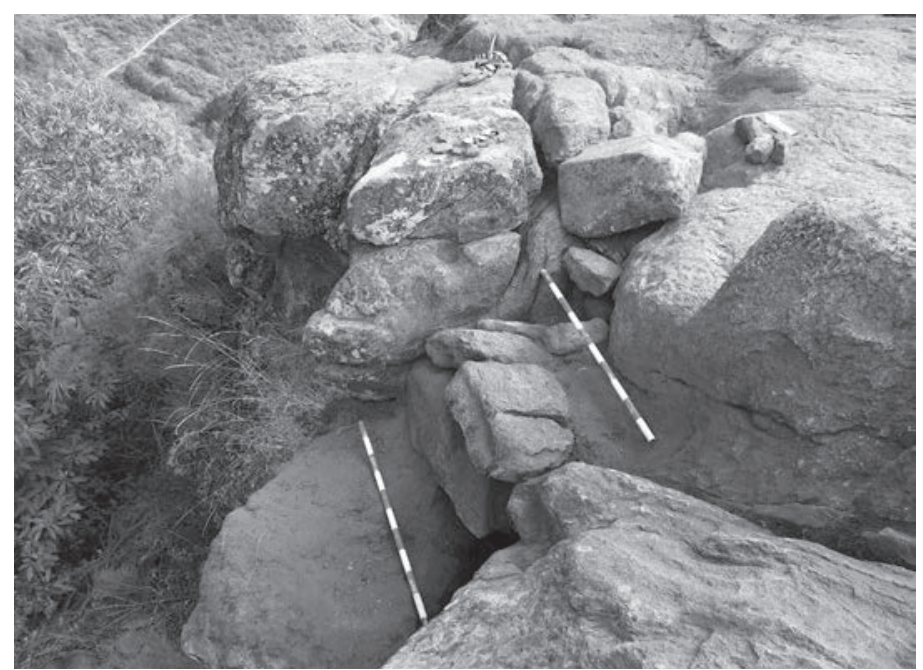

Fig. 32. Balcony in the rocky promontory oriented to the funeral area of of St. Vitor (St. Lorenzo da Barxacoba, Parada de Sil, Ourense) (from NietoMuñiz, 2014).

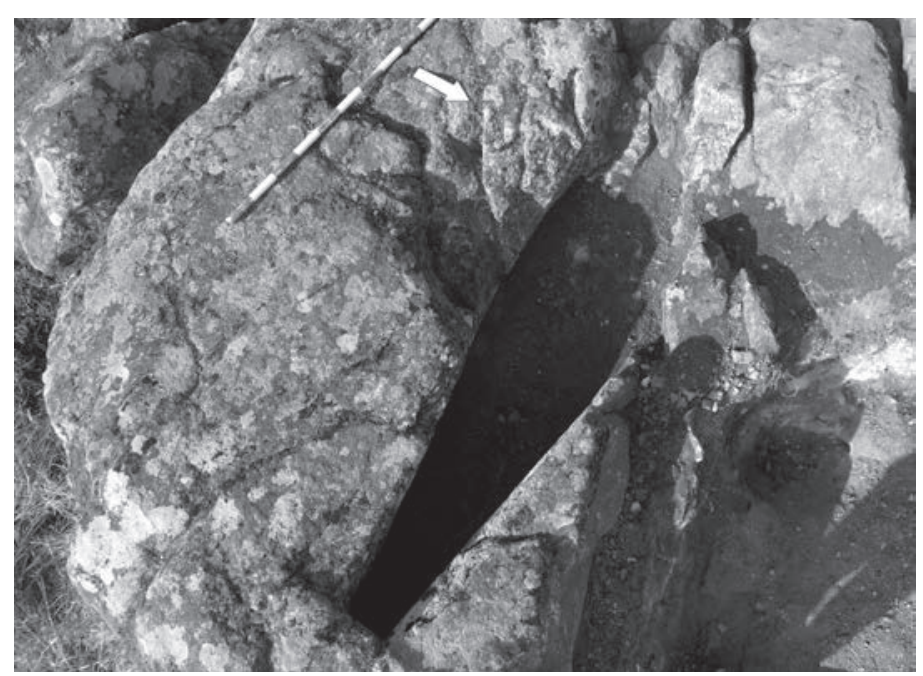

Fig. 34. Anthropomorphic tomb excavated on the rocky promontory nearly to the rupestrian hermitage in St. Vitor (St. Lorenzo da Barxacoba, Parada de Sil, Ourense) (from Nieto-Muñiz, 2014).

burial, inside the small hermitage of the rocky promontory, reusing materials from an ancient roman construction ${ }^{54}$ (fig.

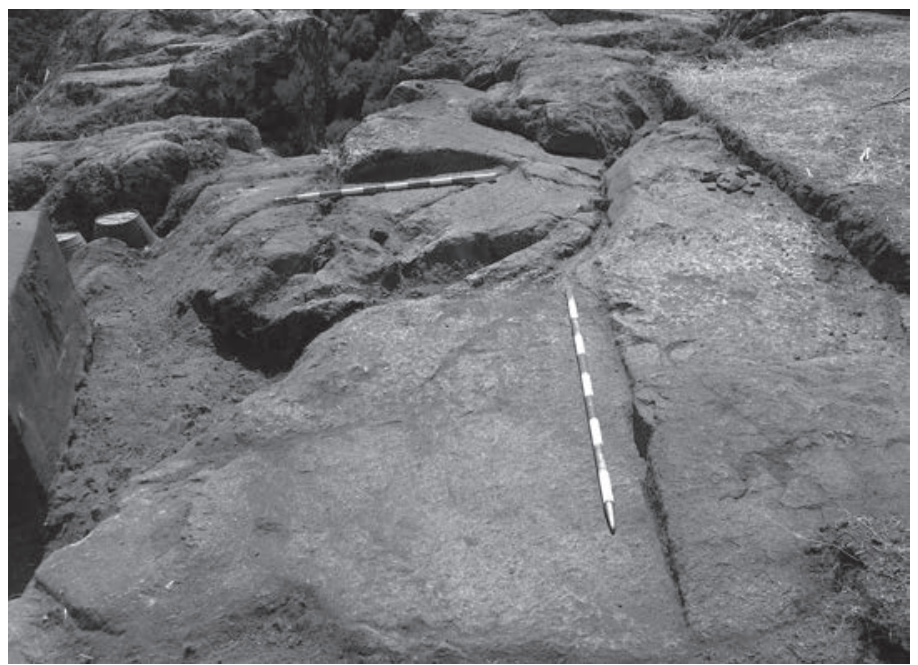

Fig. 31. Esplanade in the rocky promontory that delimits the access to the rupestrian hermitage of St. Vitor (St. Lorenzo da Barxacoba, Parada de Sil, Ourense) (from Nieto-Muñiz, 2014).

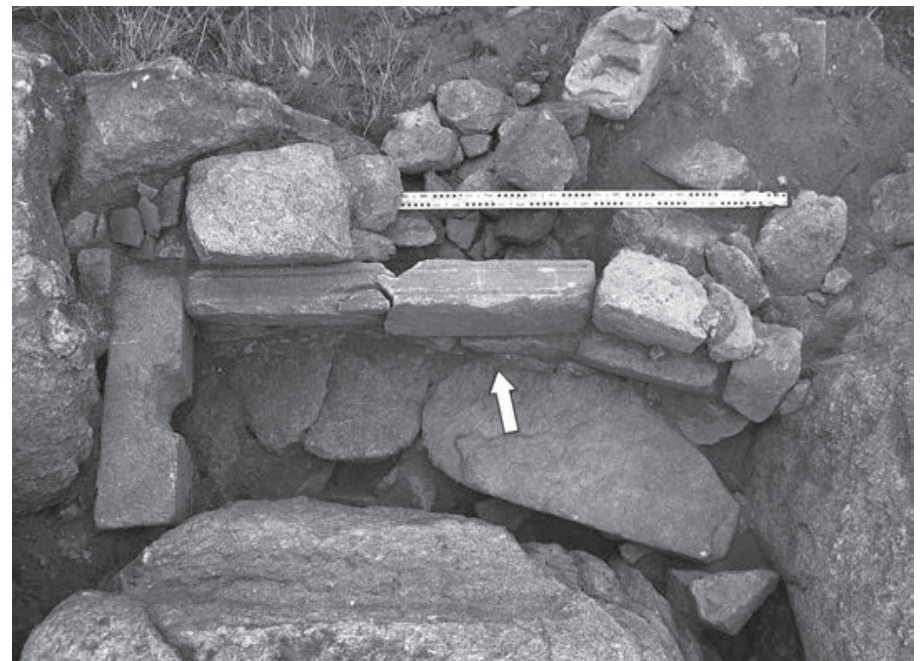

Fig. 33. Privileged burial, inside the hermitage, reusing materials from an ancient construction (St. Vitor, St. Lorenzo da Barxacoba, Parada de Sil, Ourense) (from Nieto-Muñiz, 2014).

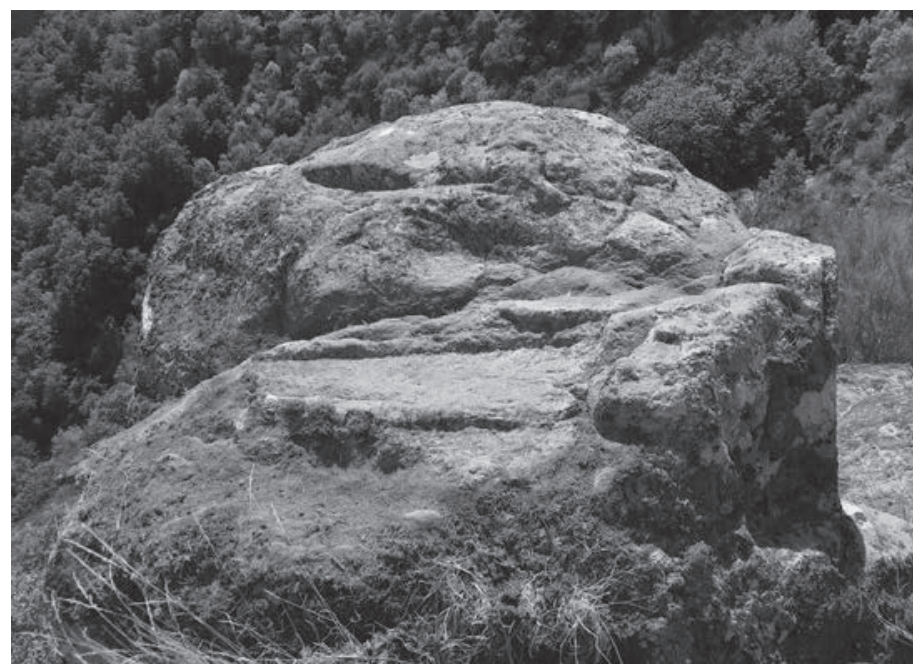

Fig. 35. Trapezoidal tomb excavated on the rocky promontory nearly to the rupestrian hermitage in St. Vitor (St. Lorenzo da Barxacoba, Parada de Sil, Ourense) (from Nieto-Muñiz, 2014).

33), with a very different typology in respect to the other tombs excavated on the rocky promontory (figs. 34 and 35 ).

${ }^{54}$ Inside the grave were found human bones in secondary position and concentrated in the header, as well as several iron objects. Among the land that covered the burial, plenty of ceramic remains, was found a real of Henry II (1369-1379): E.B. NIETO MUÑIZ - V. RODRÍGUEZ MUÑIZ, op. cit. (n. 53). 


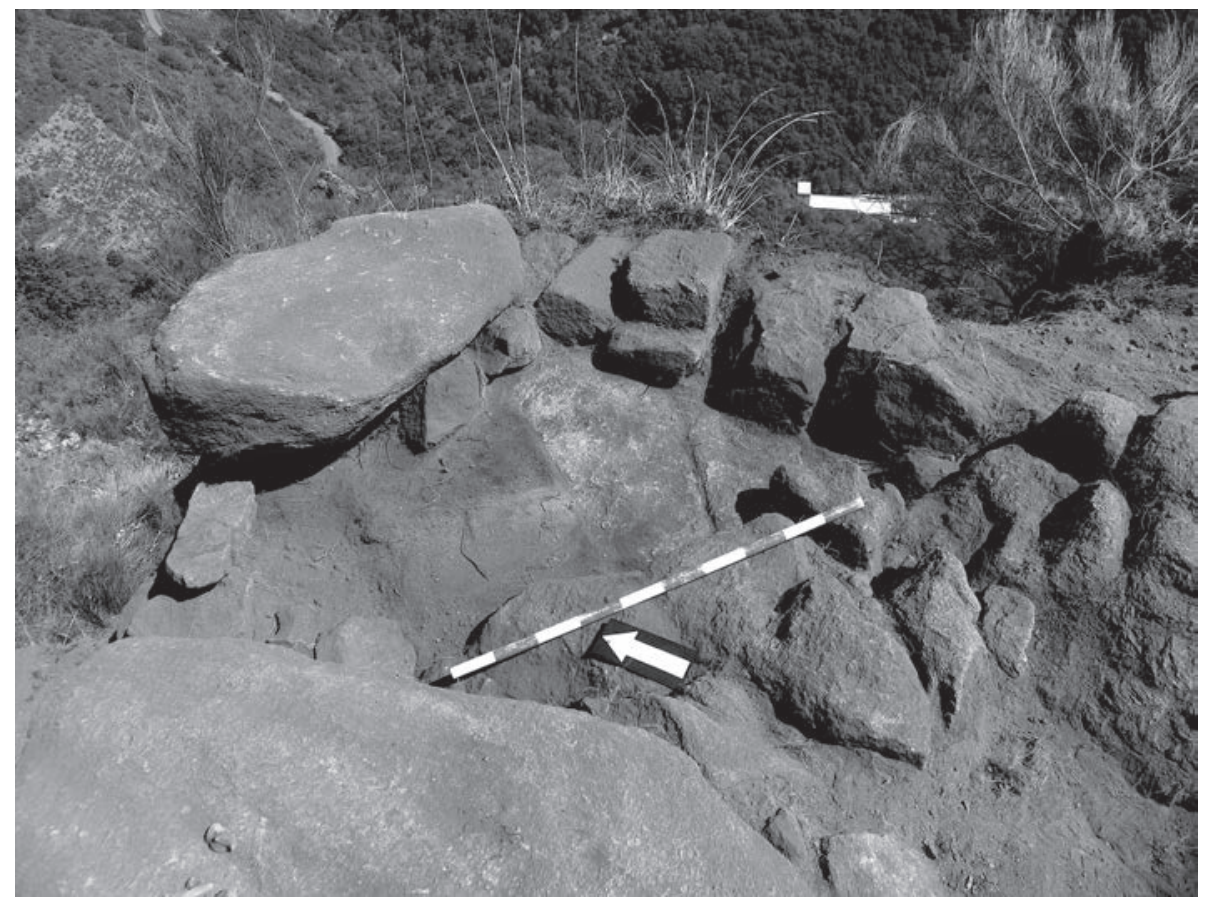

Fig. 36. Remains of a hearth in the rocky promontory next to the rupestrian hermitage in St. Vitor (St. Lorenzo da Barxacoba, Parada de Sil, Ourense) (from Nieto-Muñiz, 2014).

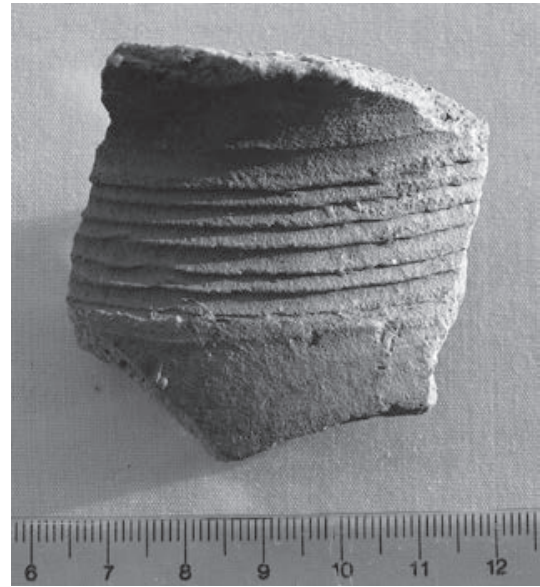

Fig. 38. Medieval pottery (12 $12^{\text {th }}-14^{\text {th }}$ centuries) found in the archaeological excavations of St. Vitor (St. Lorenzo da Barxacoba, Parada de Sil, Ourense) (from Nieto-Muñiz, 2014).

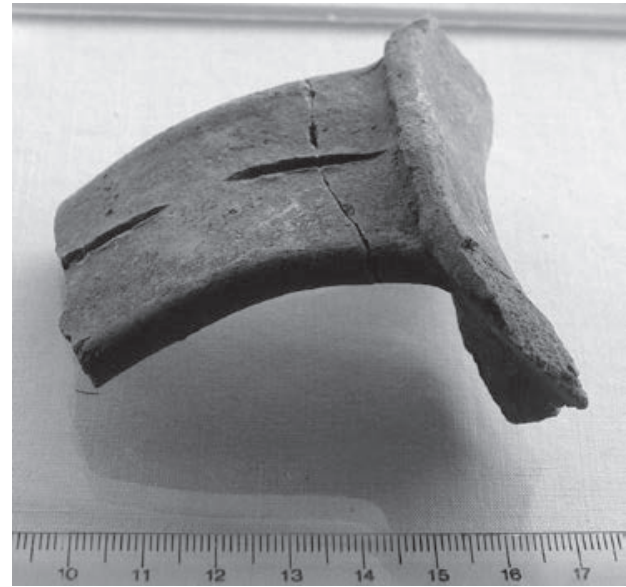

Fig. 39. Medieval pottery (12 $2^{\text {th }}-14^{\text {th }}$ centuries) found in the archaeological excavations of St. Vitor (St. Lorenzo da Barxacoba, Parada de Sil, Ourense) (from Nieto-Muñiz, 2014).

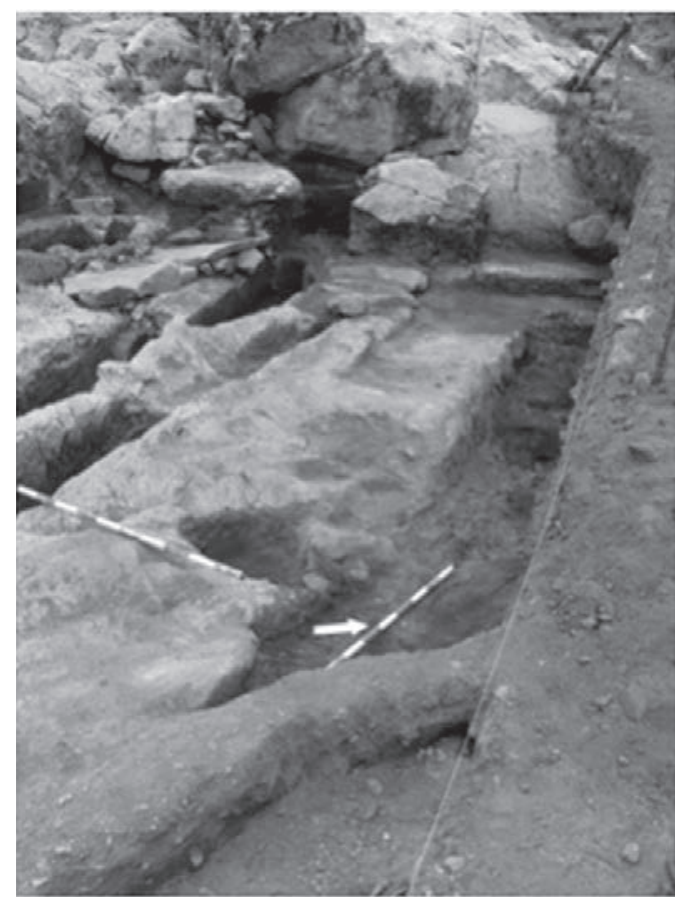

Fig. 37. Posthole and recesses in the rock for the construction of wooden buildings in the funeral area of St. Vitor (St. Lorenzo da Barxacoba, Parada de Sil, Ourense) (from Nieto-Muñiz, 2014).

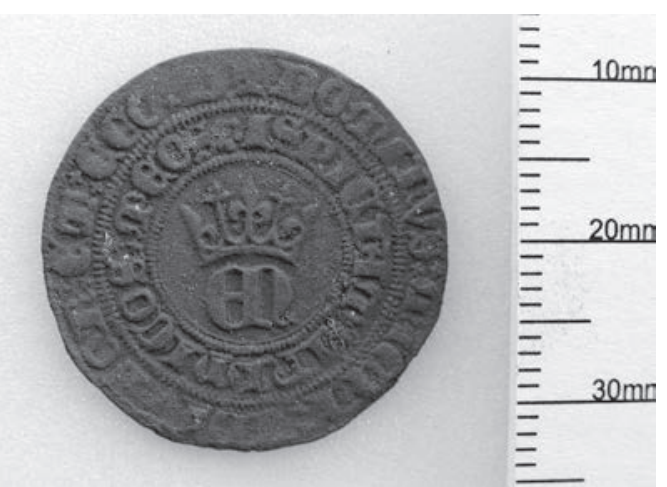

Fig. 40. Real of Henry II (1369-1379) found in the filling material of the privileged tomb inside the rupestrian hermitage of St. Vitor (St. Lorenzo da Barxacoba, Parada de Sil, Ourense) (from Nieto-Muñiz, 2014).
The funeral area of St. Vítor was developed maximizing the available space and showing a strict and planned organization in the burial distribution (fig. 29). In St. Vítor we found scarce evidence of possible rupestrian living spaces; there are the remains of a hearth in the rocky promontory where is the chapel (fig. 36) and some postholes and recesses in the rock for the construction of wooden buildings (fig. $37)^{55}$. What is unexplained, for the moment, is the absence of early medieval pottery; the most part of the ceramic materials are dated between the $12^{\text {th }}$ and the $14^{\text {th }}$ centuries, including some coins ${ }^{56}$ (figs. 38, 39 and 40). Perhaps, the answer could be under the current village of St. Lorenzo da Barxacoba, a few meters away, a small rural community over the Sil River, where it would not be surprising to find the traces of the early medieval settlement ${ }^{57}$.
Also, as in the case of the late antique hermitage and funeral area of Donato, we have for St. Vítor more questions than answers: what is St. Vítor really? A place linked to an individual Christian cult space (elitist, to some extent) that generates a funerary area of 'public' use? The devotion or holiness of a singular individual could have given rise to the configuration of an early medieval rural settlement? Can we really speak of a monastic community, given the extent and dimensions of the adjacent funerary area? Could be in origin St. Vítor a small chapel or hermitage for individual use that becomes, throughout the early Middle Ages, a kind of funeral chapel that managed a big funeral area of public burial use for one or more nearby rural communities?

Finally, the third case study leads us to the south of the Iberian Peninsula, to the rupestrian complex of Bobastro

\footnotetext{
55 Ibidem

${ }^{56}$ In addition to the real of Henry II, there is a coin of Fernando I (1367-1383) of Portugal and Sancho IV (1284-1295).

${ }^{57}$ E.B. NIETO MUÑIZ - V. RODRÍGUEZ MUÑIZ, op. cit. (n. 53); J. LÓPEZ QUIROGA, op. cit. (n. 12).
} 


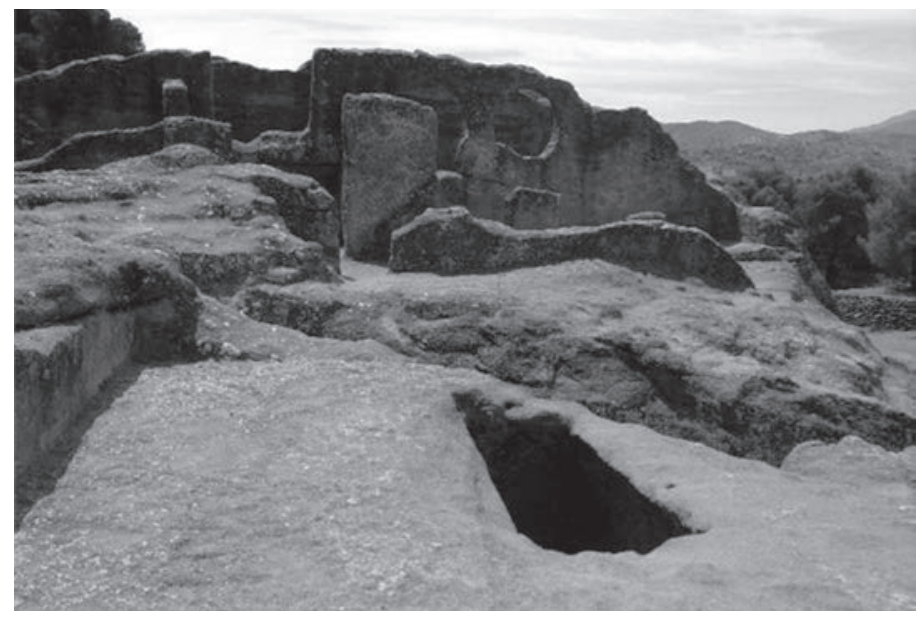

Fig. 41. Rupestrian complex of Bobastro (Málaga) (@ Paisajes Españoles).

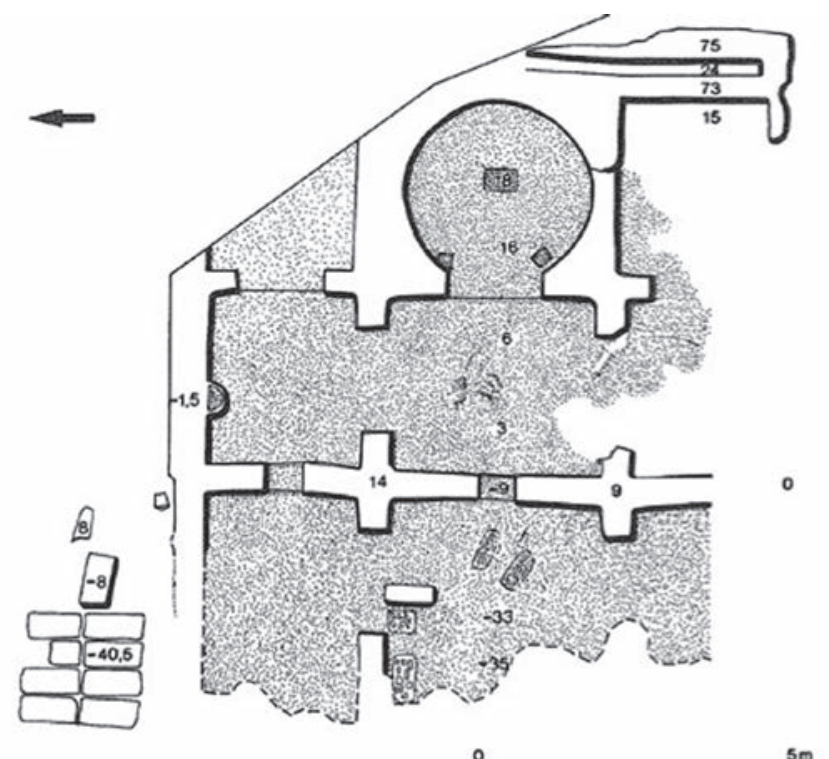

$5 m$

Fig. 43. Plant of the rupestrian church of Bobastro (Málaga) (Martinez Enamorado, 2004).

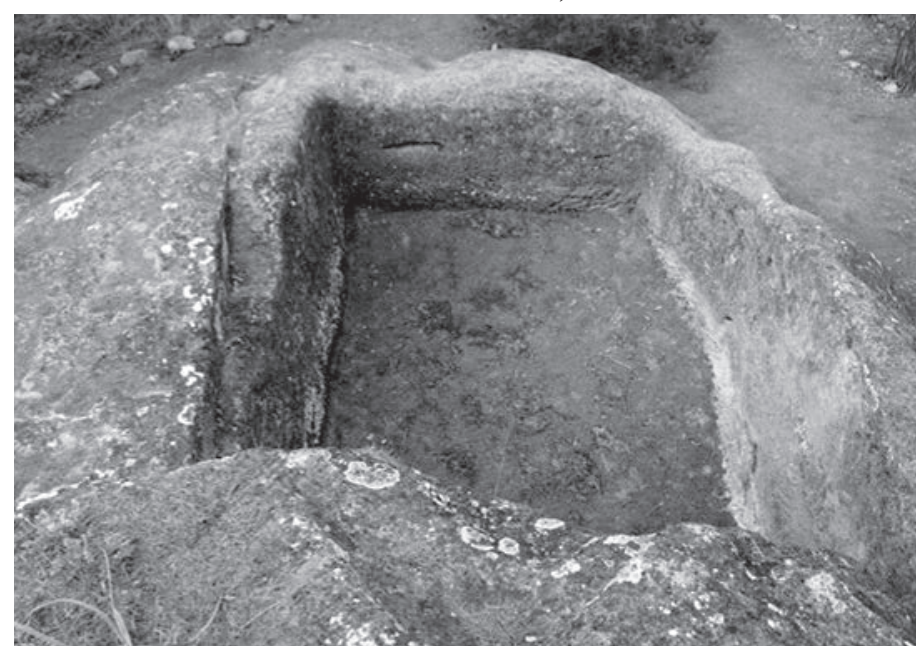

Fig. 45. Cistern excavated in the rock in the rupestrian complex of Bobastro (Málaga) (@ Paisajes Españoles).

(Mesas de Villaverde, Ardales, Málaga) ${ }^{5}$. In this place have been excavated two rupestrian churches constructed inside the madinat Bubastruh by the 'rebel' Umar Ibn Hafsun in the

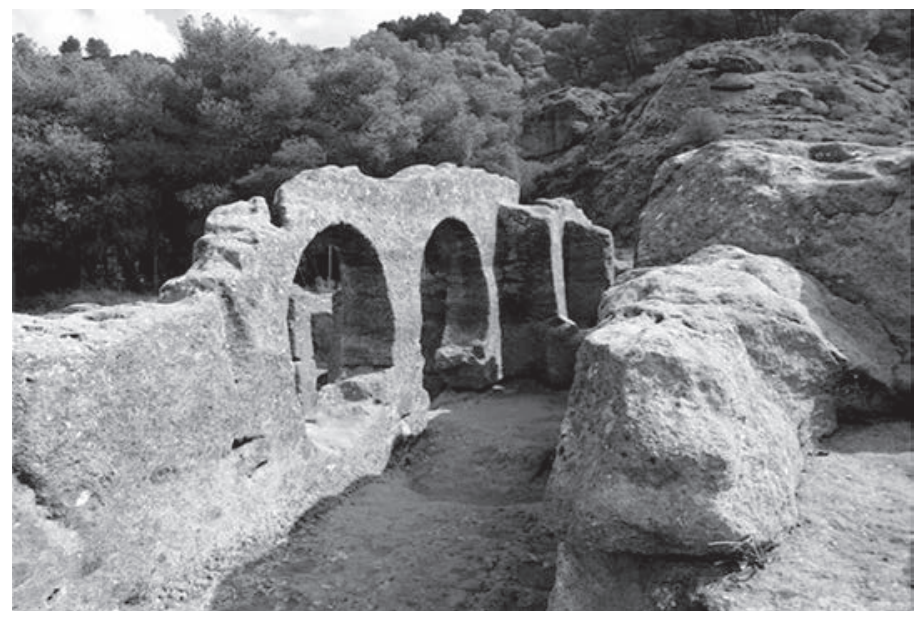

Fig. 42. Rupestrian church of Bobastro (Málaga) (@ Paisajes Españoles).

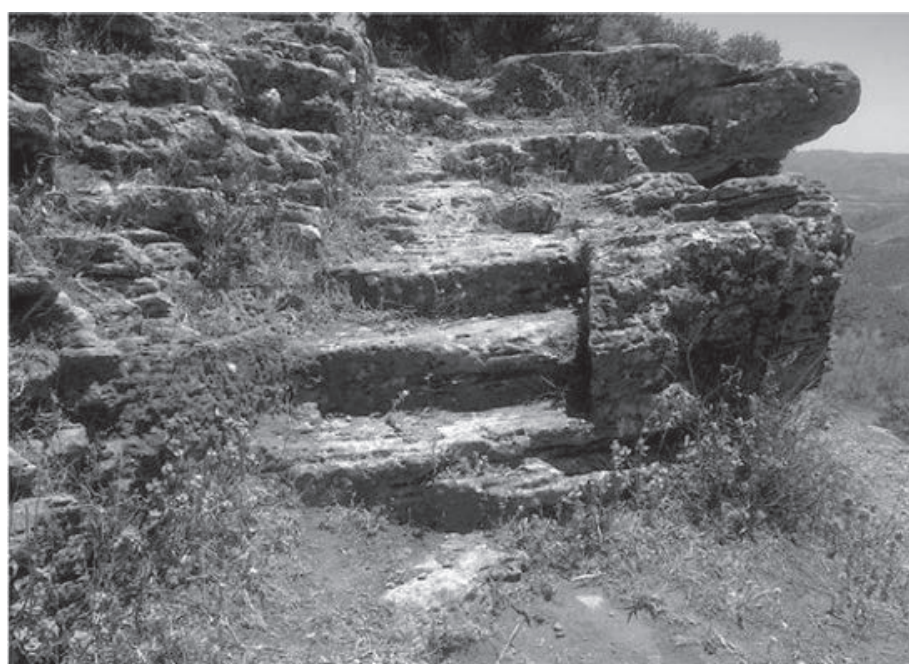

Fig. 44. Stairs excavated in the rock in the rupestrian complex of Bobastro (Málaga) (@ Paisajes Españoles).

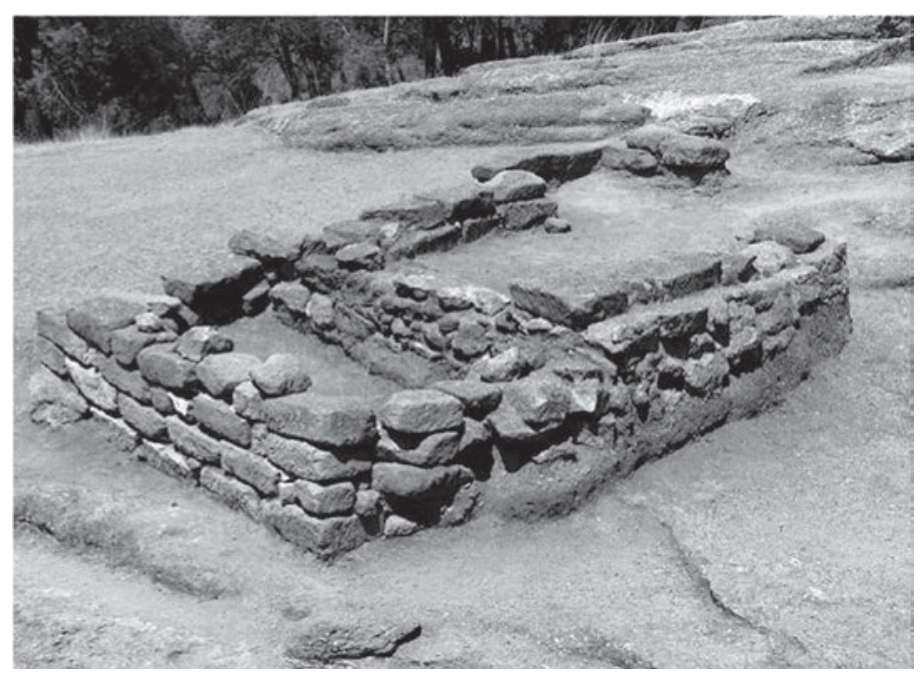

Fig. 46. Storehouse in the rupestrian complex of Bobastro (Málaga) (Martinez Enamorado, 1997).

second half of the $9^{\text {th }}$ century, in the framework of its political program of propaganda against the caliphate of Cordoba (figs. 41 and 42), consisting in the creation of two ecclesial scenarios in the most visible points of the city ${ }^{59}$. The two churches have identical architectural planning, indicative of

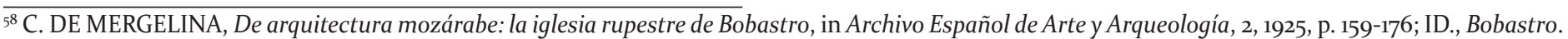
Memoria de las Excavaciones realizadas en las Mesas de Villaverde. El Chorro (Málaga) (Junta Superior de Excavaciones y Antigüedades, no 89), Madrid, 1927. 59 V. MARTÍNEZ ENAMORADO, Bobastro (Ardales, Málaga). Una madina para un 'rebelde', in Qurtuba, 2, 1997, p. 145.170. 
an intentional development: three naves, with three apses, inscribed in a rectangle (figs. 10 and 43). In addition to the two churches, throughout the rupestrian complex there are walls, cisterns, warehouses, housing, and working spaces (quarries) excavated or taking advantage of the rock as constructive material (figs. 44, 45 and 46) ${ }^{60}$.

Obviously, the recipients of this ambitious political program of propaganda were the large Christian population that remained in this area outside the domain of the Cordoba caliphate. Umar Ibn Hafsun creates ex novo a bishopric and probably one of the excavated churches may have functioned as a cathedral. The Arab chronicler al-Himyari refers to Bobastro as "seat of the Christians", adding that it has convents, churches and rupestrian constructions; without mention, however, to the presence of mosques. Those considered as monasteries of Bobastro, together with those of the region of Málaga, played an essential role in the revolt of Ibn Hafsun ${ }^{61}$. The entire complex would be razed and destroyed by Abd-al-Rhaman III, which evidences the meaning of Bobastro as centre of the hafsuní revolt lead by Ibn Hafsun (fig. 47) ${ }^{62}$.

The churches of Bobastro are not simple hermitages, like many of the rupestrian churches in the sierra of Málaga. In fact, we can consider these churches the most evident archaeological reflection of the hafsuni fitna. The topography of the two churches is also very eloquent: one in the centre of the city, as we have indicated, may have been the episcopal seat ${ }^{63}$; and the other one, in a peripheral position is interpreted as a fortified convent or dayr, to which several hermitages would be linked (figs. 48 and 49$)^{64}$.

Of course, the rupestrian complex of Bobastro adds further questions to those we have already postulated for Ercavica and St. Vítor. The terms of 'marginality' and 'isolation' acquire in Bobastro a completely different meaning from those traditionally associated with the eremitic sets. In this case, topography and architecture serve as an expression of a perfectly planned political program by Ibn Hafsun to confront the caliphate of Córdoba: an apparent invisibility that nevertheless is very present in the landscape. Religion, and the conversion to Christianity of Ibn Hafsun, is here used to convenience with political purposes and, do must not forget it, in an area under Islamic rule, as is the powerful caliphate of Córdoba.

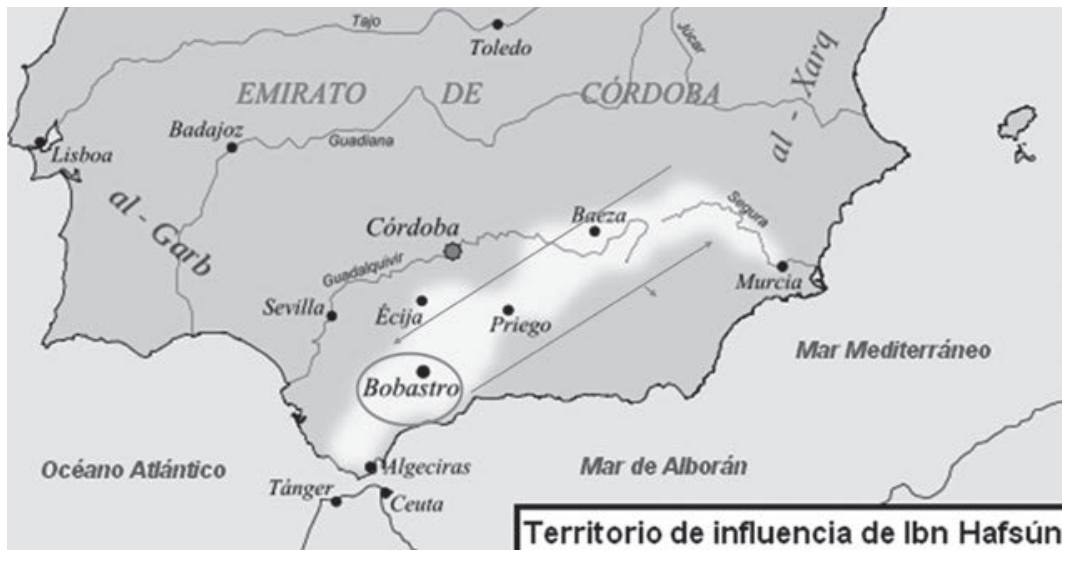

Fig. 47. Territory of influence of Ibn Hafsun from Bobastro (Málaga) (Martínez Enamorado, 1997).

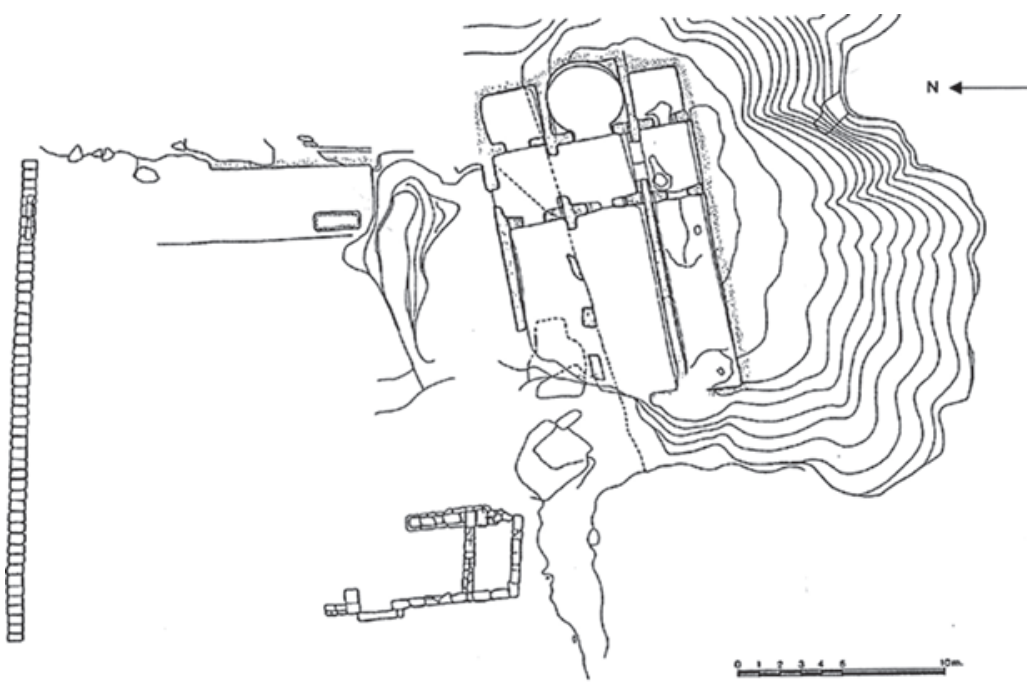

Fig. 48. Topographical position of the central church of Bobastro (Málaga) (Martinez Enamorado, 2004).

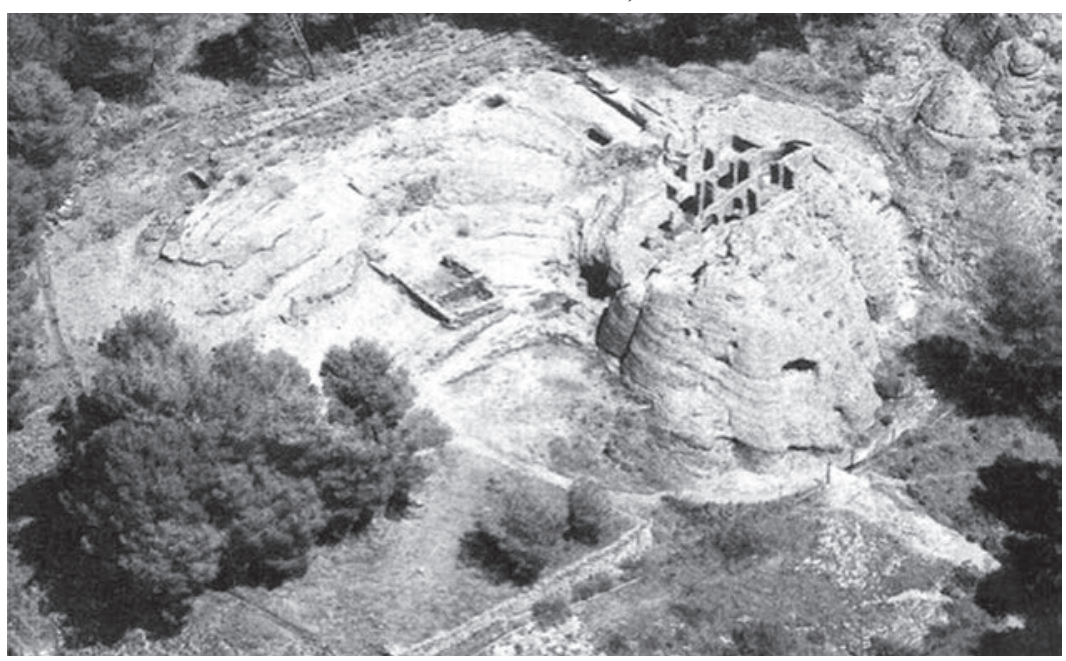

Fig. 49. Aerial view of the rupestrian complex of Bobastro (Málaga) with the strategically topographical position of the rupestrian church (@ Paisajes Españoles).

\footnotetext{
60 V. MARTÍNEZ ENAMORADO, La basílica mozárabe hallada en la ciudad de Bobastro (Ardales, Málaga). Intervención arqueológica en el cerro de La Tintilla-Mesas de Villaverde. Julio-Agosto de 2001, in Anuario Arqueológico de Andalucía, Sevilla, 2001, p. 683-691.

${ }^{6}$ V. MARTÍNEZ ENAMORADO, Bobastro (Ardales, Málaga). La ciudad de Ibn Hafsun, in Archéologie Islamique, 7, 1997, p. 27 44.

${ }^{62}$ V. MARTÍNEZ ENAMORADO, Sobre las 'cuidadas iglesias' de Ibn Hafsun. Estudio de la basílica hallada en la ciudad de Bobastro (Ardales, Málaga), in Madrider Mitteilungen, 45, 2004, p. 507-531.

${ }_{63}$ R. PUERTAS TRICAS, Excavaciones arqueológicas en las Mesas de Villaverde (Ardales, Málaga), in Anuario Arqueológico de Andalucía/1986, II:Actividades Sistemáticas, Sevilla, 1987, p. 478-480; ID., Memoria preliminar de la II campaña de excavaciones arqueológicas de 1987 en Las Mesas de Villaverde (Ardales, Málaga), in Anuario Arqueológico de Andalucía/1987, II: Actividades Sistemáticas, Sevilla, 1990, p. 371-374.

${ }^{64} \mathrm{~V}$. MARTÍNEZ ENAMORADO, op. cit. (n. 62).
} 


\section{RUPESTRIAN MONASTICISM: A SINGULAR ARCHITECTURE FOR "SOLITARY, BUT VERY ACCOMPANIED, ELITIST INDIVIDUALS"}

The eremitic origin (or at least an 'eremitic environment') of these rupestrian Christian complexes could have been certainly the starting point of many of them; but not in the case of Bobastro ${ }^{65}$. Also, some of them could give rise, and even coexisted, with monastic communities developing from rupestrian centres. Nevertheless, the marginal character or the geographical isolation of these rupestrian complexes, generally associated with its topographical situation, does not correspond with their material reality. Indeed, either from its beginnings or shortly thereafter they become settlements; in our opinion, the presence of a Christian cult place constitute, to some extent, the starting point of such settlements ${ }^{66}$. However, the archaeological knowledge that we have about the material contexts of these rupestrian complexes, especially in regards to the housing areas and production spaces, is still scarce, and very imprecise. The topographical conditions and the architecture of these rupestrian constructions constitute certainly a huge handicap. In the same way, the stereotypes and excessive simplifications that we find in a large part of the historiography that has dealt with the subject remain an important barrier, which costs to overthrow ${ }^{67}$.

The late antique and early medieval rupestrian landscapes (laurae, hermitages, churches or monasteries), together with its topographical situation, in the Iberian Peninsula raise an essential problem which, in our opinion, is key to explaining its presence: Who belong, or have belonged, the places where they are built? The question of the ownership of the land seems us, in this sense, capital. A historical question which can hardly have an archaeological answer ${ }^{68}$. In Ercavica we know, from the texts, that the lands were ceded to Donato by a gothic noble; a similar situation we found in Fructuosus of Braga, who built the monastery of St. Pedro de Montes (El Bierzo, León), in the lands donated by her father, also a gothic noble. But, what was the situation in the case of St. Vítor, or in many other rupestrian sites? That land ownership is a key issue is clearly seen in the case of Bobastro, since there is a struggle for the possession (political, religious and also symbolic) of that place. If we speak about land ownership, we are referring to individuals who have the economic capacity to own; that is, we are talking about individuals who belong to the social, political and economic elite. Therefore, and at least in the few cases that we know, they are individuals who can afford to be the impellers of an activity of this type; and even to put themselves at the 'edge of the system', as long as they do not face it ${ }^{69}$.

Rupestrian landscapes are very characteristics in their topography, which corresponds to geographical areas that had not previously been subjected to an intensive settlement and socio-economic exploitation. If we assume that these territories had an owner or owners, perhaps we should suppose that the absence of settlements and intensive economic activity in those areas would place them outside the tax control system; "out of control", in some extent. In this sense, the text of the Vita Fructuosi shows that the monasteries founded by Fructuosus of Braga in the second half of the $7^{\text {th }}$ century, escaped to the control of the Gothic state ${ }^{7^{0}}$, as they decreased the number of individuals working on rural farms and who were also obliged to serve in the 'gothic royal army' (expeditione publica) ${ }^{71}$. Therefore, the supposed marginal character of the rupestrian complexes would be more of socio-political and socio-economic type ${ }^{72}$ than a geographic reality ${ }^{73}$. And, of course, on a strictly religious level the Christian rupestrian complexes would conform a more heterodox system, somewhat uncomfortable and opposed to the orthodoxy represented by the more traditional Catholic hierarchy ${ }^{74}$. In fact, many of these places will be absorbed by more hierarchical community structures, or will simply disappear, in the context of uniformity imposed by the Gregorian reform in the $12^{\text {th }}$ century.

From the point of view of the settlement history and the occupation of the territory, the Christian rupestrian

\footnotetext{
$\overline{{ }^{6}}$ But yes in its surroundings, in the Sierra of Malaga, where there was a strong hermitical tradition. R. PUERTAS TRICAS, Iglesias rupestres de Málaga, in II Congreso de Arqueología Medieval Española, I, Madrid, 1987, p. 105-120. Aus. Nisi et duces exercitus prstres de Mñala. A. Garczo y su entorno, in an inmensus fieret chorus. Nisi et duces exercitus pr

${ }^{66}$ J. LÓPEZ QUIROGA, op.cit. (n. 36).

${ }_{77}^{6}$ R. TEJA CASUSO, Los orígenes del monacato (siglos IV-V), in Actas del I Seminario sobre El Monacato (Codex Aqvilarensis 1), Aguilar de Campoo, 1988, p. 15-30; ID., Monacato e historia social: los orígenes del monacato y la sociedad del Bajo Imperio Romano, in Homenaje a Marcelo Vigil, Salamanca, 1989, p. 127-173; P. C. Díaz Martínez, Formas económicas y sociales del monacato visigodo, Salamanca, 1987; ID., Ascesis y monacato en la Península Ibérica antes del siglo VI, in J.L. Martín (ed.), I Congreso de Historia de Salamanca, I, Salamanca, 1988, p. 205-226.

${ }^{68}$ J. LÓPEZ QUIROGA, op. cit. (n. 12).

${ }^{69} \mathrm{~J}$. LÓPEZ QUIROGA - M. RODRÍGUEZ LOVELLE, La Hispania del siglo VII a través de la 'Vita Fructuosi', in Famille, Violence et christianisation au Moyen Âge. Mélanges offerts à Michel Rouche (Études réunies par Martin Aurell et Thomas Deswarte) (Cultures et Civilisations médiévales 31), Paris, 2005, p. 195-207.

$7^{\circ}$ Vita Frut., 14: 23-31: «Sicut a religioso uiro Iuliano presbitero qui in eodem cenobio adoleuit ex paruulo, fideli relatione cognoui, breuiter intimabo. Tanti glorisissimi et incoparabilis uiri rutilo fulgore radians exempla meritorum ita aradore fidei accendit animos populorum ut cateruatim undique concurrens agmina conuersorum inmensus fieret chorus. Nisi et duces exercitus prouinciae illius uel circumseptus undique confinibus regi clamasset ut aliquantum proiberetur, quia si fas fuerit permissionis se debuit congregare exercitus monachorum».

${ }^{71}$ J. LÓPEZ QUIROGA, Actividad monástica y acción política en Fructuoso de Braga, in Hispania Sacra, 54, 109, 2002, p. 7-22; ID., op.cit. (n. 36); ID., Después del 'final' de las villae entre el Miño y el Duero (ss. VII-X): comunidades 'fructuosianas', hábitat rupestre y aldeas, in J. López Quiroga - C. Fernández Ochoa - M. Conceiçâo Lopes (eds.), Formas de ocupación rural en la Gallaecia y la Lusitania en la Antigüedad Tardía y la alta Edad Media (Cuadernos de Prehistoria y Arqueología de la Universidad Autónoma de Madrid, 31-32, 2005-2006), Madrid, 2006, p. 219-246.

${ }^{72}$ As evidenced by the Liber Iudicum for the second half of the $7^{\text {th }}$ century (within a period of profound political crisis: in less than thirty years five kings were proclaimed and so many rebellions and conspiracies took place in Hispania) with 21 laws dedicated to fugitiuis et occultatoribus fugamque preuetibus in times of Chindasvinto, Ervigio, Egica and Witiza.

${ }^{73}$ J. LÓPEZ QUIROGA, op.cit. (n. 36).

${ }^{74}$ P.C. DÍAZ MARTÍNEZ, El eremitismo en la Hispania visigoda: Valerio del Bierzo y su entorno, in El monacato espontáneo: eremitas y eremitorios en el mundo medieval, J.A. García de Cortazar - R. Teja (eds.), Aguilar de Campoo, 2011, p. 57-84.
} 
complexes represent an extension of the inhabited and socioeconomically exploited space that began in the Late Antiquity and continued more intensively during a good part of the Early Middle Ages ${ }^{75}$. The rupestrian monasticism (in its anchorite and/or eremitic versions), emerged from an individual initiative of elitist type (that configures an "elitist architecture" $)^{76}$, served as a focus of attraction and germ of many rural settlements of undoubted villager character. Its distinctive landscape, at all geographically isolated or marginal, gives them a unique allure throughout a very singular architecture. The debate on whether we should put more emphasis on the 'point of arrival' (rural settlements) than on the 'departure point' (places of Christian worship) is, in our opinion, completely sterile and excessively reductionist, since we cannot explain and understand one without the other. 